\title{
Milk as a Complex Multiphase Polydisperse System: Approaches for the Quantitative and Qualitative Analysis
}

\author{
Alena Smirnova ${ }^{1,2, *}$, Georgii Konoplev ${ }^{3}$, Nikolay Mukhin ${ }^{3,4, *} \mathbb{0}$, Oksana Stepanova ${ }^{3}$ and \\ Ulrike Steinmann ${ }^{5}$ (D) \\ 1 State Institution “Ustyuzhenskaya Regional Station of Preventing and Monitoring Animal Diseases", \\ 162800 Vologda Region, Russia \\ 2 Institute of Experimental Medicine of the North-West Branch of the Russian Academy of Medical Sciences, \\ 197376 Saint Petersburg, Russia \\ 3 Department of Photonics, Saint Petersburg Electrotechnical University "LETI", \\ 197376 Saint Petersburg, Russia; gakonoplev@mail.ru (G.K.); oksana_lopatenko@mail.ru (O.S.) \\ 4 Institute for Micro and Sensor Systems, Otto von Guericke University of Magdeburg, \\ 39106 Magdeburg, Germany \\ 5 Institute for Automation Engineering, Otto von Guericke University of Magdeburg, \\ 39106 Magdeburg, Germany; ulrike.steinmann@ovgu.de \\ * Correspondence: alena.smirnova.e93@gmail.com (A.S.); mukhin.nikolay.v@gmail.com or \\ nikolay.mukhin@ovgu.de (N.M.)
}

Received: 10 September 2020; Accepted: 12 October 2020; Published: 15 October 2020 updates

\begin{abstract}
Milk is a product that requires quality control at all stages of production: from the dairy farm, processing at the dairy plant to finished products. Milk is a complex multiphase polydisperse system, whose components not only determine the quality and price of raw milk, but also reflect the physiological state of the herd. Today's production volumes and rates require simple, fast, cost-effective, and accurate analytical methods, and most manufacturers want to move away from methods that use reagents that increase analysis time and move to rapid analysis methods. The review presents methods for the rapid determination of the main components of milk, examines their advantages and disadvantages. Optical spectroscopy is a fast, non-destructive, precise, and reliable tool for determination of the main constituents and common adulterants in milk. While mid-infrared spectroscopy is a well-established off-line laboratory technique for the routine quality control of milk, near-infrared technologies provide relatively low-cost and robust solutions suitable for on-site and in-line applications on milking farms and dairy production facilities. Other techniques, discussed in this review, including Raman spectroscopy, atomic spectroscopy, molecular fluorescence spectroscopy, are also used for milk analysis but much less extensively. Acoustic methods are also suitable for non-destructive on-line analysis of milk. Acoustic characterization can provide information on fat content, particle size distribution of fat and proteins, changes in the biophysical properties of milk over time, the content of specific proteins and pollutants. The basic principles of ultrasonic techniques, including transmission, pulse-echo, interferometer, and microbalance approaches, are briefly described and milk parameters measured with their help, including frequency ranges and measurement accuracy, are given.
\end{abstract}

Keywords: milk composition; multiphase polydisperse system; near-infrared spectroscopy; mid-infrared spectroscopy; Raman spectroscopy; milk optical and acoustical properties; milk spectral analysis; speed of sound; attenuation; ultrasonic techniques 


\section{Introduction}

Milk is one of the most common foods. Dairy products are important dietary sources of calcium because of its high content, high absorption rate, availability, and relatively low cost. They contain more protein, calcium, potassium, magnesium, zinc, and phosphorus per calorie than any other popularly food found in our diet [1]. Regular consumption of milk improves enamel in children, promotes better absorption of vitamins, and prevents dehydration of the body. According to research by the Annals of Internal Medicine, dairy consumption reduces acidity throughout the body. But when using milk, it should be borne in mind that some people may have lactose intolerance and may have problems digesting milk because of the lactose contained in it [2-4]. The dynamics of growth in the production and consumption of dairy products is observed annually [4].

The safety and quality of raw milk is now a key competitive factor in the industry. The main reason for the low quality of milk is the lack of effective organization of technological processes. Optimization of quality control of dairy products remains a pressing issue. Gradually, along with traditional methods of analysis, which take a long time, require chemical reagents and preliminary sample preparation, express analyzers are being introduced more and more. Now the market for equipment for the analysis of milk and dairy products is represented by very diverse new models. Such equipment can perform analysis on several indicators in a short time.

All express analyzers are united by the fact that working with them is not difficult for a non-professional, they do not require additional reagents for operation, they are capable of operating at least $8 \mathrm{~h}$, they can be transported and calibrated according to their samples. But despite all the advantages of modern analyzers, there are issues that have not yet been resolved. The most common and interesting devices for further modernization work on the basis of optical, spectroscopic, and ultrasonic methods of analysis.

Optical spectroscopy is among the most widely used methods for the routine quality control of milk and dairy products since it provides fast, simple, and reliable analytical procedures with minimal sample preparation.

Mid-infrared (MIR) spectroscopy has been successfully used for the quantitative determination of the principal milk constituents (protein, fat, lactose) for decades and became some kind of a gold standard; apart from improving accuracy and reliability, the recent developments in this area were aimed at the detection of milk adulteration, the problem which is extremely acute worldwide. Fourier transform infrared (FTIR) spectrometers with attenuated total reflection (ATR) accessories are largely used for the MIR spectral analysis of milk. While there is an obvious market demand for on-site and in-line applications, the high cost of FTIR spectral equipment and the intrinsic limitations of ATR measurements hamper the implementation of MIR spectroscopy outside off-line, laboratory conditions.

Near-infrared (NIR) spectroscopy provides relatively low-cost and robust solutions suitable for in-line applications on milking farms and dairy production facilities, including devices incorporated in milking robots and industrial processing equipment. Because of the significant advances in chemometrics NIR technologies of milk analysis have now achieved the level of accuracy and reliability only slightly inferior to MIR spectroscopy.

Different aspects of milk spectral analysis are discussed in this section of the review: optical properties of milk in a wide spectral range $(0.2-25 \mu \mathrm{m})$, various analytical techniques, the spectral equipment. The emphasis was made on the methods, which are widely employed for routine milk quality control, namely MIR and NIR molecular absorption spectroscopy (spectrophotometry). Spectroscopic techniques, which are not so extensively used, including ultraviolet (UV) absorption spectroscopy, Raman spectroscopy, atomic spectroscopy, and molecular fluorescent spectroscopy are also briefly described.

The following are acoustic methods that are suitable for non-destructive analysis of milk. This article discusses the acoustic properties of milk and acoustic methods for measuring the speed of sound, attenuation, density. Questions about how the acoustic properties of milk are related to its ingredients are discussed. It is discussed how acoustic characterization can provide information on fat 
content, particle size distribution of fat and proteins, and the kinetics of changes in the biophysical properties of milk over time, the content of specific proteins and pollutants.

The basic principles of ultrasonic measuring techniques, including transmission, pulse-echo, interferometer, and microbalance approaches, are briefly described and examples of milk parameters measured with their help, including frequency ranges and measurement accuracy, are given.

\section{Milk as a Complex Multyphase Polydisperse System: Urgent Tasks}

\subsection{Milk Industry and Actual Problems}

It is known that milk and dairy products belong to the group of products of daily consumption and accompany a person throughout his life; many studies have been done and published on the effect of milk on human health [4-8]. The world market is mainly represented by such types of milk as cow, buffalo, goat, sheep, and camel. The dynamics of the annual increase in milk yield is shown in Figure 1a.

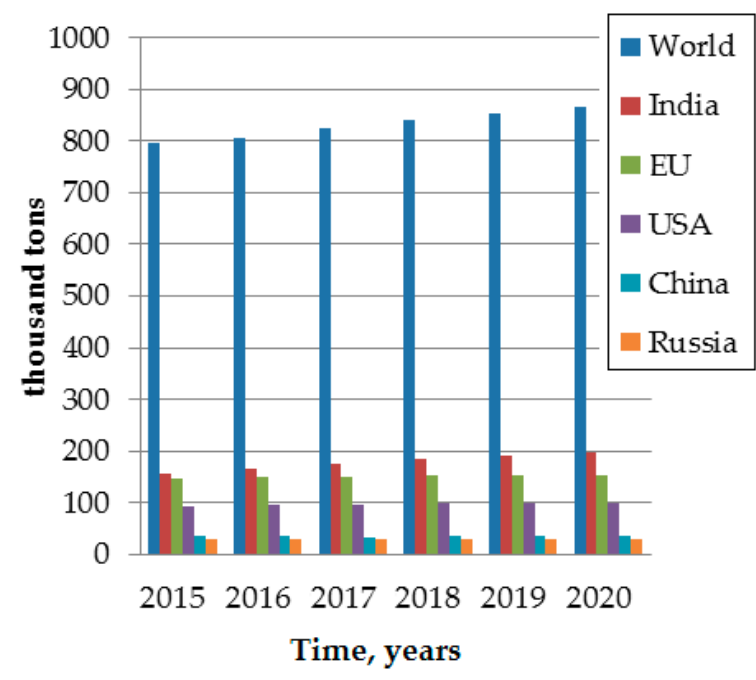

(a)

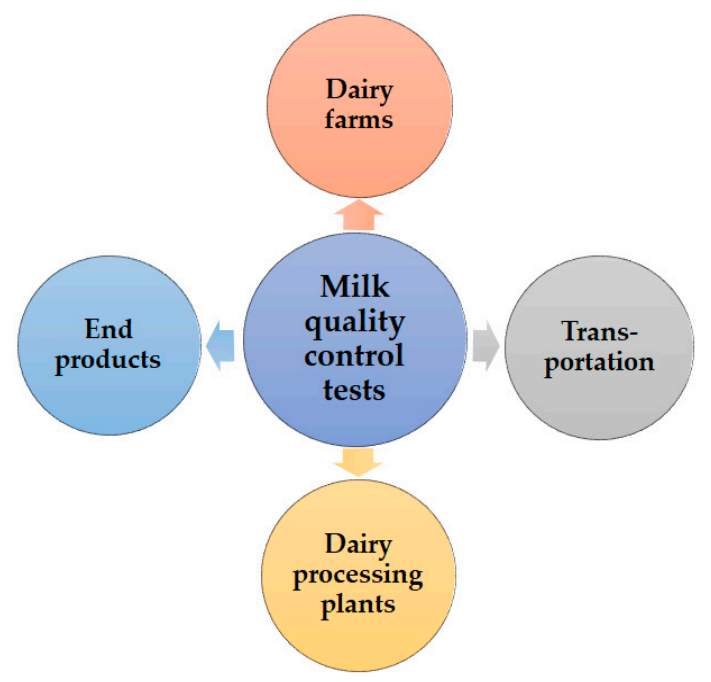

(b)

Figure 1. Production of all types of milk according OECD-FAO Agricultural Outlook [9] (a) and relevance of milk tests $(\mathbf{b})$.

The annual consumption of dairy products in Russia reaches $16 \%$ of all types of food [7]. In the conditions of the current deficiency of animal protein, it is imperative to include dairy products in the diet. According to the Ministry of Health, the rate of consumption of milk and dairy products per person in Russia is $325 \mathrm{~kg}$ per year [7]. However, according to Rosstat reports, Russians receive less than $30 \%$. So in 2018, Russians consumed less than $230 \mathrm{~kg}$ of dairy products, and in $2019-229 \mathrm{~kg}$. In China, according to the «Dietary Guidelines for Chinese Residents», the daily consumption of milk and dairy products should be $300 \mathrm{~g}$ per day or $109.5 \mathrm{~kg}$ per year. But according to IFCN, the average is only $31 \mathrm{~kg}$ per capita per year (or $85 \mathrm{~g}$ per day). The low level of consumption of dairy products is due to cultural and historical features. In India, the recommended rate is the same as in China, $109.5 \mathrm{~kg}$ per year, while the real consumption exceeds the nominal and averages $131 \mathrm{~kg}$ per year. European countries have a high level of consumption of dairy products. The average is $306 \mathrm{~kg}$ per year. According to the recommendations of the German Society for Healthy Nutrition (DGE, Deutsche Gesellschaft für Ernährung), it is recommended to consume 200-250 g of milk and low-fat dairy products daily, 2 slices of low-fat cheese (50-60 g), i.e., about $91-113 \mathrm{~kg}$ of milk per per capita year. According to the «2015-2020 Dietary Guidelines for Americans» [6], developed in the United States and used as a guide in some countries, the recommended level of dairy consumption for children aged 9-18 and adults is about 3 "cup-equivalents," that is about $1137.7 \mathrm{~g}$ per day or $415 \mathrm{~kg}$ per year. 
The real indicator of consumption of milk and dairy products in 2015 in the United States was $269 \mathrm{~kg}$ per capita per year. According to The DairyNews, citing Dairy Repoter, Switzerland also does not consume enough dairy products. Thus, the annual consumption of milk per inhabitant has decreased over 20 years from 79 to $53.3 \mathrm{~kg}$.

In general, an important problem in the world remains the lack of raw milk and the deficit in both total volume and quality. The reasons for this situation are multifaceted-there is a decrease in the total livestock population, production of low-quality products, insufficient breeding work, outdated methods of keeping and feeding animals, outdated and worn out equipment, a shortage of personnel (both highly qualified and working personnel), unpopularity of the profession, low prices for raw milk, low investment attractiveness (the dairy industry is traditionally an industry with a low payback level), long payback periods.

Currently, an urgent problem in dairy farming is to ensure the quality and safety of raw milk as the main raw material for dairy products. Quality management should be considered as a purposeful process of coordinated actions in the system of the dairy complex of the agro-industrial complex to establish, ensure, and maintain the required quality level of marketable products that meets the requirements of customers and processing enterprises. Quality is the fundamental factor that makes up competitiveness. This also applies to agricultural producers, whose products must compete successfully in a free market economy. Competent assessment of raw milk allows to prevent and reduce losses, increase sales income.

Milk has a short shelf life. Its quality directly depends on the fulfillment of conditions at all stages of production: from collection at the farm level, transportation, acceptance, and processing at the dairy. Therefore, sampling and analysis must be carried out throughout the milk processing line. Modern industrial processing based on high-tech processes makes high demands on the quality of milk used as raw material for the production of a wide range of dairy products (Figure 1b).

Some large producers make their requirements for raw materials, which are often quite strict in terms of protein, fat, and somatic cells content, while reducing the purchase prices for milk of a lower grade. The solution to improve the quality and reduce the cost of equipment can be new efficient and inexpensive technologies that would allow assessing the quality of milk produced. The problems faced by the agricultural producer are the ingress of low-quality raw milk into the general flow (milk pipeline, cooling tanker). For example, milk from cows with mastitis (open or closed form), contamination of raw materials with microorganisms from an insufficiently treated udder of a cow, poor-quality disinfection of dairy equipment, etc. In this case, the raw material becomes either unsuitable for further use and processing, or its grade decreases, and as a consequence, the purchase price decreases. Dairies cannot produce a quality product from such raw materials, and farms suffer significant losses.

Another important question is the composition of milk. Its chemical composition not only determines its nutritional and biological value, but also affects the technological processing, yield, and quality of finished products $[10,11]$. The content of individual components in milk is not constant; it changes depending on the stage of lactation, breed, and health status of animals [12], quality of feed, season, age, individual characteristics, conditions of maintenance, milking technique, etc. [13,14]. During processing and production of products, milk is subjected to mechanical, thermal, and chemical treatments that change its characteristics, which affects the technological processes and properties of the final product $[10,11,15]$. If the raw milk does not meet the necessary requirements, then the final product will be of inadequate quality. Therefore, it is very important that already at the farm level it is possible to determine the composition of milk from each group of cows. This will allow adjusting the ration of the dairy herd and culling the livestock in time.

\subsection{Milk Composition and Main Parameters}

The main indicators that characterize the quality of milk are: chemical composition, degree of purity, organoleptic, biochemical, physical and mechanical properties, as well as the presence of toxic and neutralizing substances in it. 
Milk contains more than a hundred organic (fat, proteins, carbohydrates, enzymes, vitamins, hormones) and inorganic (water, mineral salts, pigments, gases) substances [16]. Milk consists of water and food substances distributed in it-fats, proteins, carbohydrates, enzymes, vitamins, minerals, gases [17] (Figure 2).

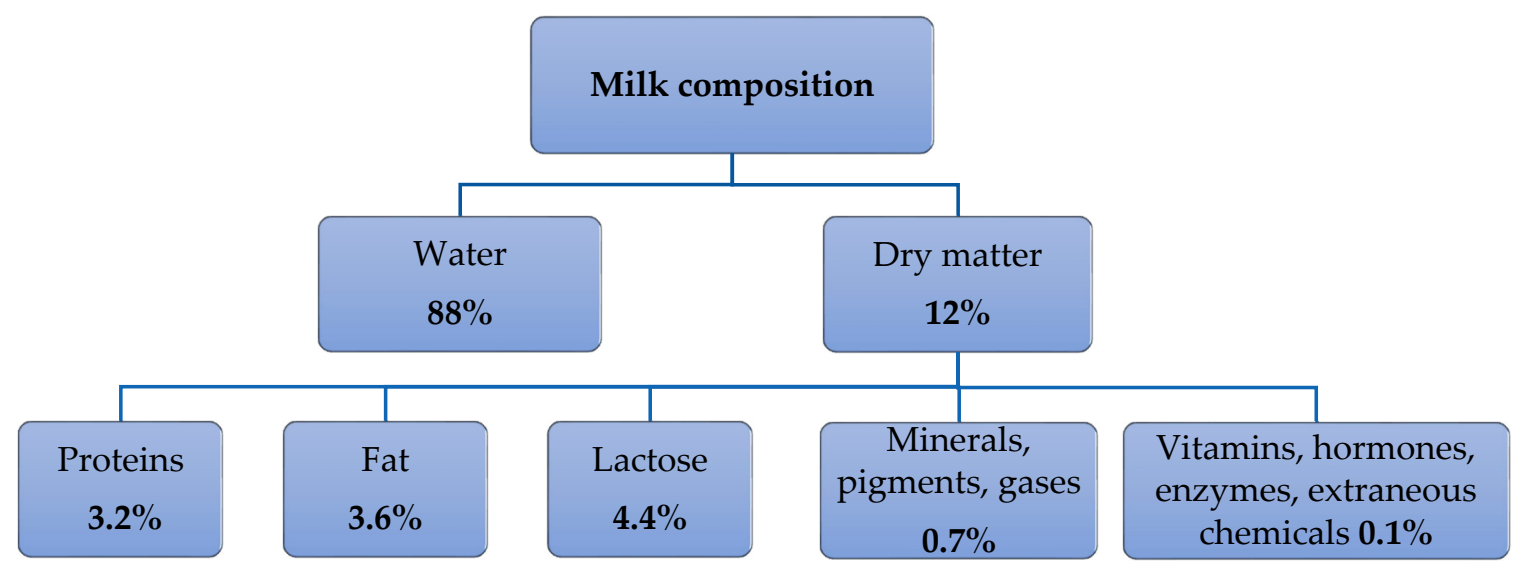

Figure 2. Milk composition.

In terms of physical composition, milk is a complex polydisperse system containing many interconnected structural formations.

These structures include an emulsion dispersed system of fat globules, the structural system is colloidal, it consists of protein particles $0.2-1$ microns in size. The composition of milk also includes a fractional system-true solutions of scattered molecules and atoms.

In milk quality control, samples are checked for acidity, antibiotic content, added water, fat, and protein. These analytical tests and methods are determined by international standards.

\subsubsection{Milk Fat}

Milk fat is the most variable in composition and concentration component of milk [18], its content in cow's milk ranges from 2.8 to $6.3 \%$. Milk sold to the consumer is standardized with a range of different fat content choices. It is a source of energy and essential fatty acids (linoleic, arachidonic), fat-soluble vitamins (A, D, E, K). Until recently, the economic value of milk was based precisely on the fat content of milk.

Milk fat is an ester of a trihydric alcohol of glycerol and fatty acids. Triacylglycerols (triglycerides) represent $97-98 \%$ of the total lipids in the milks. It also contains accompanying fat-like substances, or natural impurities [19]. These include phospholipids (the presence of hydrophilic and hydrophobic parts in their molecules contributes to the formation of emulsions that are stable in water), glycolipids (are biologically active components, preventing the production of enterotoxins in the body by certain types of bacteria), sterols (part of the membranes of fat globules), fat-soluble pigments (karotin, etc., determine the color of milk), fat-soluble vitamins. Despite the insignificant amount of impurities, some of them significantly affect the nutritional value of milk fat [20].

Fat in milk is a dispersed system of fat globules and is an oil-in-water emulsion, the properties of which have a marked effect on many properties of milk, such as color, taste and viscosity. The globules in bovine milk range in diameter a mean of $\sim 3.5 \mu \mathrm{m}$ (from $\sim 0.1$ to $\sim 20 \mu \mathrm{m}$ ). The size distribution of fat globules in milk may be determined by light microscopy, light scattering (Malvern Mastersizer), or electronic counting devices (the Coulter counter) [21,22].

\subsubsection{Milk Proteins}

The content of milk protein is an important component of milk, both a source of good nutrition (contains 18 amino acids, including 9 essential amino acids) and a factor in determining the price of 
milk [23]. The protein in milk ranges from 2.9 to $4 \%$. The proteins in milk can be fractionated into two defined groups: casein and serum protein. The ratio of casein to whey proteins consists is 80:20. Casein is in the form of relatively large colloidal particles-micelles and contains four fractions $(\alpha S 1, \alpha S 2$, $\beta$, and $k$-caseins) and their fragments. Whey proteins are heterogeneous and include globular proteins that differ in structure and properties- $\beta$-lactoglobulin, $\alpha$-lactoglobulin, immunoglobulins, lactoferrin, and serum albumin. The third group can be distinguished, these include proteins of the shells of fat globules, which make up only about $1 \%$ of all milk proteins. The milk proteins contain the nine essential amino acids required by humans, making it an important human food [24,25].

\subsubsection{Lactose}

Lactose (milk sugar) is a ready source of energy, participates in the formation of the nervous system, skin, bone, and cartilage tissue in childhood and prevent bone loss in the elderly [26].

The lactose content in milk of cows is 3.6-5.6 (4.7\% on average). Lactose is a disaccharide built from D-glucose and D-galactose residues linked by a 1.4-glycosidic bond. Lactose is 5-6 times less sweet than sucrose and less soluble in water. In milk, milk sugar is in two forms: $\alpha$ and $\beta$. At $20^{\circ} \mathrm{C}$ contains $40 \% \alpha$-lactose and $60 \% \beta$-lactose. Both forms can transform one into another, the rate of transition from one form to another depends on the temperature. When milk is heated to a temperature above $100{ }^{\circ} \mathrm{C}$ (especially during sterilization and high-temperature processing), milk sugar is partially converted into lactulose. Lactulose differs from milk sugar in that it contains fructose instead of glucose. Lactulose is readily soluble in water, $1.5-2$ times sweeter than lactose. At high heating temperatures $\left(160-180{ }^{\circ} \mathrm{C}\right)$, milk sugar caramelizes, and the lactose solution turns brown.

\subsubsection{Minerals, Vitamins, Urea, Enzymes, Hormones, and Other Ingredients}

Mineral substances in milk contain from 0.6 to $0.8 \%$. The main macronutrients include: calcium, magnesium, potassium, sodium; microelements: copper, iron, zinc, cobalt, manganese, iodine, etc. Milk contains almost all vital vitamins. They are represented by fat-soluble (A, D, E, K) and water-soluble (B1, B2, B3, PP, B6, B9, B12, C, H) vitamins. Another important component of milk is urea. Monitoring the level of urea in milk and blood allows to adjust the feeding diet in a timely manner, as well as improve the quality of milk and dairy products. Urea is also added to improve the thermal stability of milk and to increase the total nitrogen content (milk protein), which is a type of adulteration. Milk also contains more than 20 native enzymes, hormones (prolactin, oxytocin, somatotropin, thyroxin), pigments (carotenoids that determine the color of milk), gases such as nitrogen, oxygen, carbon dioxide, ammonia (they get into milk from blood, air during milking, pipeline transport), etc.

Thus, the composition of milk is complex and unstable, and the absence of one of the substances or a deviation of its quantity from the norm usually indicates a sick state of the animal, an inadequacy of the diet (feed) or falsification of milk.

\subsubsection{Falsification}

On the list of the most counterfeited foods in the world, milk follows immediately after olive oil; over the past 30 years, milk has featured in $24 \%$ of all incidents [27]. Since the composition and properties of milk fluctuate (Table 1) under the influence of various factors, this in practice makes it possible to falsify milk in different ways.

The methods of falsification have practically not changed in recent years. At the moment, two large groups of counterfeit can be distinguished-the falsification of the composition (mainly raw materials) and the falsification of quality. The most common counterfeit is dilution with water [28], milk whey (Table 2), the addition of nitrogen-containing substances, milk substitutes, preservatives [18,22,29]. 
Table 1. Average chemical composition of cow's milk and range of fluctuations in the norm.

\begin{tabular}{lcc}
\hline \multicolumn{1}{c}{ Components } & Average Content, $\%$ & Oscillation Limits \\
\hline Water & 87.5 & $84-89$ \\
Dry matter & 12.5 & $11-16$ \\
Including: & & \\
Fat & 3.8 & $2.5-6.8$ \\
Protein & 3.3 & $2.7-5.0$ \\
Lactose & 4.7 & $3.6-5.6$ \\
Ash & 0.7 & $0.6-0.9$ \\
\hline
\end{tabular}

Table 2. Comparison of the chemical and physical properties of whole and falsified milk.

\begin{tabular}{cccc}
\hline Parameters & Diluted with Water & Whole Milk & Skimmed Milk \\
\hline $\begin{array}{c}\text { organoleptic } \\
\text { characteristics }\end{array}$ & $\begin{array}{c}\text { weakened taste and odor, } \\
\text { decreased viscosity } \\
\text { (wateriness), bluish color }\end{array}$ & $\begin{array}{c}\text { specific smell, no foreign } \\
\text { impurities, color from } \\
\text { white to light cream }\end{array}$ & $\begin{array}{c}\text { taste is significantly } \\
\text { reduced, a bluish tint, } \\
\text { wateriness is acquired }\end{array}$ \\
\hline density, $\mathrm{kg} / \mathrm{m}^{3}$ & $<1027$ & $1027-1032$ & $1030-1035$ \\
\hline viscosity at $20{ }^{\circ} \mathrm{C}, \mathrm{mPa} \cdot \mathrm{s}$ & 1.2 & 2.127 & 1.79 \\
\hline acidity, $\mathrm{To}$ & $<16$ & $16-21$ & without changes \\
\hline dry residue, $\%$ & $<10$ & 12.2 & changes slightly \\
\hline fat, $\%$ & $<3.2$ & 3.6 & $<2.8$ \\
\hline protein, $\%$ & $<2.5$ & $2.8-3.2$ & without changes \\
\hline
\end{tabular}

The most important components of milk, fats and proteins are objects of falsification. The mass fraction of protein is determined by the official standard methods of Kjeldahl and Lowry [30,31]. For example, the Kjeldahl method calculates the mass fraction of all nitrogenous compounds, then multiplying by a factor of 6.38 to find the mass fraction of total protein in milk. Some of these compounds are normal products of the animal's body and are present in milk normally. But other nitrogen may also be present in the milk-for example, mineral nitrogen compounds that get into the milk with feed, the content of which sometimes exceeds in the feed, or intentionally introduces nitrogen-containing substances to increase the protein content in the milk. According to the Kjeldahl method, the content of any nitrogen will be calculated as milk protein.

When milk fat is falsified, it is replaced with cheaper plant analogues. Such substitutes can be of high quality, characterized by the presence of both hydrogenated and non-hydrogenated fats, and a low level of trans isomers. The most common chemical methods for measuring fat content are the Gerber method [32] and the Rose-Gottlieb method [33]. At the same time, the analyzes last 1.5-2 h, they are sensitive to foreign impurities used in the preparation of samples, chemical reagents are required, which in many cases are harmful to laboratory workers. Receiving milk requires simple, safe, and quick methods.

\subsection{Commercial Milk Analyzers}

Dairy farming and working conditions are changing at a fast pace. Dairy farms today use modern automation tools, embrace digital technologies, and implement intelligent solutions for profitable and efficient milk production. The market for equipment for the analysis of milk and dairy products is very diverse and is constantly being replenished with various new models, both from manufacturers that have been working in this field for a long time, and from manufacturers previously not present on the market. All equipment can be conditionally divided into two groups: which operates on the basis of direct methods of analysis (extraction, weighing, etc.) and equipment that uses indirect methods of obtaining data on the composition of the sample. 
The first group includes any devices that determine the mass, temperature, and equipment designed to conduct the actual chemical analysis with varying degrees of automation. For example, "Kjeldahl devices", which are represented by a wide variety of models in a wide price range, but, accordingly, with the same wide range of capabilities.

The second group includes instruments using instrumental analysis methods. This is a large number of various devices using spectroscopy in different ranges [34-36], devices using ultrasonic vibrations [37,38], measuring the optical activity of the sample, as well as "combined devices", in which two methods can be applied at once, or preliminary sample preparation (for example, precipitation or "binding" of any component of the sample), followed by analysis of the sample thus obtained by a standard method (for example, optical spectroscopy).

About 10 years ago, the study of milk and dairy products was only possible under laboratory conditions, and was based on chemical or physicochemical methods. Since these are direct methods, they are considered the most reliable, but such an analysis is a laborious, long-term (analysis could take up to $15 \mathrm{~h}$ ) process that requires experience and specialized knowledge from personnel, high-purity chemicals. This leads to an increase in the cost of the examination of raw materials, in addition, the accuracy of the results may decrease because of imperfect reagents, the human factor-laboratory assistant errors and subjective assessment of the results. Often a situation arises when the indicators of the device used, calibrated according to the manufacturer's data, differ from the indicators obtained by reference methods, for example, the Gerber method for determining fat. The difference can be significant, say $0.3 \%$ fat. With the apparent simplicity of the method, forgetting about its intricacies can lead to systematic errors in the analysis. For example, the temperature regime is not maintained, the isomeric composition of the isoamyl alcohol used is not monitored. This leads to discrepancies between the readings of the milk analyzer and the results obtained from the chemical analysis data precisely because the control analysis method (Gerber's method) was performed incorrectly.

In addition, the modern pace of life and production constantly requires an increase in the speed of all stages of production. Owing to new technologies, quality analysis is carried out much faster and does not depend so much on the qualifications of employees. Therefore, now more and more often give preference to analyzers that use indirect methods of data collection.

Despite all the advantages of modern analyzers, there are areas that still need to be refined. Equipment for agricultural producers must meet a number of requirements. First, it should be inexpensive and competitive. So the average cost for present analyzers ranges from $340 €$ to $22,660 €$ and more, depending on the modernization (Table 3). Second, it should be easy to use. If we talk about the analysis of milk quality directly on farms, then the best option is the ability to adapt to any milk pipeline, without making significant changes to the structure of the milk pipeline and without breaking the vacuum regime. Third, the analyzer must take into account the heterogeneity of the milk flow in the milk pipe. Milk is a complex polydisperse system. Milk sugar (lactose) is dissolved in a dispersed medium (water: $85-89 \%$ ) of milk, the size of its molecules is $1-1.5 \mathrm{~nm}$. Milk salts are in the form of colloidal particles, protein substances form colloidal solutions. Milk fat is in a warm state in the form of an emulsion, in a cold state-in the form of a suspension. The process of milk movement through the pipeline of the milking installation is unsteady, from laminar to turbulent modes. It is also necessary to take into account the heterogeneity of the milk-air flows because of the mechanical effect on the milk, leading to foaming. This complicates the determination of milk quality parameters. Fourth, the analyzer must carry out tests as quickly as possible. The best option is to work in real time, directly in the stream. There is currently no automatic counter-sensor for linear installations. Non-independent manufacturers (De Laval, GEA PHARM Technologies, etc.) offer mobile milking machines for use. They have small dimensions and do not interfere with the measured flow. However, they have a significant cost and high error (up to $10-12 \%$, with the maximum allowable rate not exceeding $5 \%$ ). Thus, at the moment there are no analyzers that could meet all modern requirements. 
Table 3. Comparative characteristics of commercial milk analyzers.

\begin{tabular}{|c|c|c|c|c|c|c|}
\hline Specifications & Klever-2 [39] & Lactan [40] & Ekomilk [41] & Lactoscan [42] & Bentley [43] & MilkoScan [44] \\
\hline Manufacturer & Russia & Russia & Bulgaria & Bulgaria & USA & Denmark \\
\hline $\begin{array}{l}\text { Price range } \\
\text { depending on } \\
\text { equipment, } €\end{array}$ & $464-878$ & $340-850$ & $645-1530$ & from 815 & from 67,000 & from 66,000 \\
\hline Device weight, $\mathrm{kg}$ & 1 & 3 & 3.5 & 1.5 & 45.4 & 72 \\
\hline $\begin{array}{c}\text { Continuous working } \\
\text { time, hours }\end{array}$ & 12 & no more than 8 & no data & no limits & no limits & no limits \\
\hline $\begin{array}{l}\text { Vestigated objects } \\
\text { (depending on } \\
\text { modification) }\end{array}$ & $\begin{array}{l}\text { Milk and dairy } \\
\text { products }\end{array}$ & $\begin{array}{l}\text { Fresh, canned, } \\
\text { pasteurized } \\
\text { normalized milk }\end{array}$ & $\begin{array}{c}\text { Whole fresh } \\
\text { cow, sheep, goat milk }\end{array}$ & $\begin{array}{c}\text { Cow's, sheep's, } \\
\text { buffalo's \& goat's } \\
\text { milk, } \\
\text { cream, serum }\end{array}$ & $\begin{array}{c}\text { Raw \& pasteurized } \\
\text { milk, whey, fat cream } \\
\text { up to } 20 \% \text {, cream up } \\
\text { to } 50 \% \text { fat, skim milk, } \\
\text { yogurt. }\end{array}$ & $\begin{array}{l}\text { Milk and dairy } \\
\text { products }\end{array}$ \\
\hline $\begin{array}{c}\text { Temperature of } \\
\text { sample, }{ }^{\circ} \mathrm{C}\end{array}$ & $5-35$ & $15-35$ & $5-35$ & $5-40$ & $38-42$ & $5-55$ \\
\hline $\begin{array}{c}\text { Average } \\
\text { measurement time of } \\
1 \text { sample }\end{array}$ & $\begin{array}{l}22 \text { samples per hour, } \\
3.5 \text { min per sample }\end{array}$ & $\begin{array}{l}\text { No more than } 5 \text { min } \\
\text { per sample }\end{array}$ & $\begin{array}{l}\text { 65-70 samples per } \\
\text { hour, } 40 \text { s per sample }\end{array}$ & $\begin{array}{l}60 \text { s (30 s are } \\
\text { optional). }\end{array}$ & $\begin{array}{c}\text { 400-600 samples per } \\
\text { hour }\end{array}$ & 30 s per sample \\
\hline $\begin{array}{l}\text { Fat, } \\
\text { error, \% }\end{array}$ & $\begin{array}{l}0-20 \\
\pm 0.06\end{array}$ & $\begin{array}{c}0-10 \\
\pm 0.05 \\
5-10, \pm 0.1\end{array}$ & $\begin{array}{c}0.5-12 \\
\pm 0.1\end{array}$ & $\begin{array}{c}0.01-25 \\
\pm 0.06-0.1\end{array}$ & $\begin{array}{c}0-50 \\
\pm 0.1-0.5\end{array}$ & $\begin{array}{c}0-60 \\
\pm 0.06-0.5\end{array}$ \\
\hline $\begin{array}{l}\text { Protein, } \\
\text { error, \% }\end{array}$ & $\begin{array}{l}0.15-6 \\
\pm 0.15\end{array}$ & $\begin{array}{c}1.5-3.5 \\
\pm 0.1\end{array}$ & $\begin{array}{l}2-6 \\
\pm 0.2\end{array}$ & $\begin{array}{c}2-7 \\
\pm 0.08-0.15\end{array}$ & $\begin{array}{l}0-15 \\
\pm 0.3\end{array}$ & $\begin{array}{c}0-7 \\
\pm 0.14-0.3\end{array}$ \\
\hline $\begin{array}{c}\text { Density, } \\
\text { error, } \mathrm{kg} / \mathrm{m}^{3}\end{array}$ & $1000-1050, \pm 0.3$ & $1000-1040, \pm 0.3$ & $1026-1033, \pm 0.3$ & $1000-1150, \pm 0.3$ & $1000-1100, \pm 0.3$ & $1025-1037, \pm 0.4$ \\
\hline $\begin{array}{l}\text { Added water, } \\
\text { error, \% }\end{array}$ & $\begin{array}{c}\text { 3-70, } \\
\text { no data }\end{array}$ & $\begin{array}{c}0-100 \\
\pm 1\end{array}$ & $\begin{array}{l}0-60 \\
\pm 5\end{array}$ & no data & no data & $\begin{array}{c}0-100 \\
\pm 1\end{array}$ \\
\hline
\end{tabular}




\section{Optical Spectroscopic Approaches and Techniques for Milk Analysis}

\subsection{Optical Properties of Milk in a Wide Spectral Range}

Attenuation of optical radiation propagating through a medium is a consequence of two fundamental physical phenomena of light-matter interaction-absorption and scattering; according to the Beer-Lambert law the intensity of radiation $I_{\lambda}$ decreases exponentially [45]:

$$
I_{\lambda}=I_{0 \lambda} \exp \left[-\mu_{\mathrm{e}} \cdot d\right]=I_{0 \lambda} \exp \left[-\left(\mu_{\mathrm{a}}+\mu_{\mathrm{es}}\right) \cdot d\right],
$$

where $I_{0 \lambda}$ is the intensity of incident radiation; $\mu_{\mathrm{a}}$ is the bulk absorption coefficient; $\mu_{\mathrm{s}}$ is the bulk scattering coefficient; $\mu_{\mathrm{e}}=\mu_{\mathrm{a}}+\mu_{\mathrm{s}}$ is the extinction coefficient, which includes both absorption and scattering; $d$ is the thickness of an optical layer. The absorption and scattering coefficients $\mu_{\mathrm{a}}$ and $\mu_{\mathrm{s}}$, along with the refractive index $\mathrm{n}$ and the scattering anisotropy factor $g$ [46] are referred to as bulk optical properties of a medium [47]. For highly turbid media, where multiple scattering events take place on the optical path, more sophisticated mathematical description of radiative transfer than the classical Beer-Lambert law may be needed [48,49].

For the purpose of optical radiation transfer analysis, milk can be represented as a three-phase inhomogeneous composite liquid medium consisting of the serum, the fat globules, and the casein micelles [50]. The serum (or whey) is an aqueous solution of whey proteins, lactose, vitamins, electrolytes, and other water-soluble components of milk. The fat globules are spherical lipid droplets, which form a stable emulsion in the serum, the size of the droplets in raw milk lies in the wide range from a few hundred nanometers up to $10 \mu \mathrm{m}$ [51], but it can be sufficiently reduced and uniformed in the process of homogenization [52]. The casein micelles are solid spherical formations dispersed in the serum; they are formed of the insoluble casein proteins which represented up to $80 \%$ of all proteins in milk. These micelles vary in sizes from $50 \mathrm{~nm}$ to $680 \mathrm{~nm}$ (the mean diameter is about $200 \mathrm{~nm}$ ) which are smaller than the diameter of fat globules [50].

The milk serum may be slightly opaque, but elastic scattering of photons occurs mainly on the fat globules and casein micelles. Taking into account that the sizes of these spherical particles $\mathrm{P}$ are comparable with the wavelengths of radiation $\lambda$ in a considerable part of the optical region $0.1 \lambda<\mathrm{P}<\lambda$, the Mie theory should be applied to analyze elastic light scattering in milk [51]. It is a highly turbid medium because the fraction of the scattering particles is very substantial: the concentration of fat in raw milk can achieve $8 \%$, casein content can be as high as $3 \%$ [50]. In molecular absorption spectroscopy (spectrophotometry) the main challenges when dealing with such samples are distinguishing and separating absorption and scattering effects in the experimental data (usually reflectance and transmittance spectra), and subsequent recovering of the bulk optical properties [47]. For raw milk, this task is even more complicated because the distribution of scattering particle by size is not known beforehand and depends on many factors [51].

Alongside with the fat globules and casein micelles, somatic cells (primarily leucocytes with the diameter of $8.5-10 \mu \mathrm{m}$, which should be considered as an additional type of scattering particles) are always present in relatively small amounts even in normal milk. In case of inflammation (cow mastitis) the concentration of these cells is elevated; in the process of milk quality assessment it is necessary to control that it is below a certain threshold. This can be done by optical methods because somatic cells influence milk scattering properties [53].

In the Table 4 the wavelengths (wavenumbers) of the characteristic absorption of several important milk constituents are summarized; the strongest absorption bands, which are often used for quantitative spectral analysis, were selected in a wide spectral range $(0.2-25 \mu \mathrm{m})$. 
Table 4. The wavelengths/wavenumbers of the main milk constituents' characteristic absorption in a wide spectral range.

\begin{tabular}{|c|c|c|c|c|}
\hline $\begin{array}{l}\text { Spectral } \\
\text { Region }\end{array}$ & $\begin{array}{l}\text { Wavelength } \\
\text { Interval }\end{array}$ & $\begin{array}{c}\text { Milk } \\
\text { Constituents }\end{array}$ & $\begin{array}{c}\text { Absorption } \\
\text { Wavelengths/Wavenumbers }\end{array}$ & Reference \\
\hline $\begin{array}{l}\text { Ultraviolet and } \\
\text { visible }\end{array}$ & $0.2-0.7 \mu \mathrm{m}$ & $\begin{array}{l}\text { proteins } \\
\quad \text { fat } \\
\beta \text {-carotene } \\
\text { riboflavin }\end{array}$ & $\begin{array}{c}280 \mathrm{~nm} \\
205,230,270 \mathrm{~nm} \\
435 \mathrm{~nm}, 480 \mathrm{~nm} \\
449 \mathrm{~nm}\end{array}$ & $\begin{array}{c}{[53-56]} \\
{[57]} \\
{[58]}\end{array}$ \\
\hline Near infrared & $0.7-2.5 \mu \mathrm{m}$ & $\begin{array}{c}\text { water } \\
\text { whey protein } \\
\text { fat }\end{array}$ & $\begin{array}{c}970,1200,1450,1940, \\
1953,1984 \mathrm{~nm} \\
1731,1774,2056,2060, \\
2167,2180 \mathrm{~nm} \\
1220,1720,1730,1740-1770, \\
1780,2076,2270 \\
2310,2340,2386 \mathrm{~nm} \\
1450,1680,1720,1730,1780, \\
1820,1980,2100,2310, \\
2340,2790 \mathrm{~nm} \\
1450,1820,2100,2340 \mathrm{~nm}\end{array}$ & $\begin{array}{c}{[47]} \\
{[59]} \\
{[47,60,61]}\end{array}$ \\
\hline Middle infrared & $\begin{array}{c}2.5-25 \mu \mathrm{m} \\
\left(4000-400 \mathrm{~cm}^{-1}\right)\end{array}$ & $\begin{array}{c}\text { water } \\
\text { fat } \\
\text { proteins }\end{array}$ & $\begin{array}{c}1640,3300 \mathrm{~cm}^{-1} \\
1175,1470,1754,2857 \mathrm{~cm}^{-1} \\
1240,1600-1700 \\
1550-1570 \mathrm{~cm}^{-1} \\
1052,1080,1157 \mathrm{~cm}^{-1}\end{array}$ & $\begin{array}{c}{[62]} \\
{[63]} \\
{[62,63]}\end{array}$ \\
\hline
\end{tabular}

The diagram in the Figure 3 shows the most practically significant optical spectroscopic techniques for milk analysis; molecular absorption spectroscopy (spectrophotometry) is dominant among them for the purpose of the qualitative determination of the main milk constituents and some adulterants in routine milk testing.

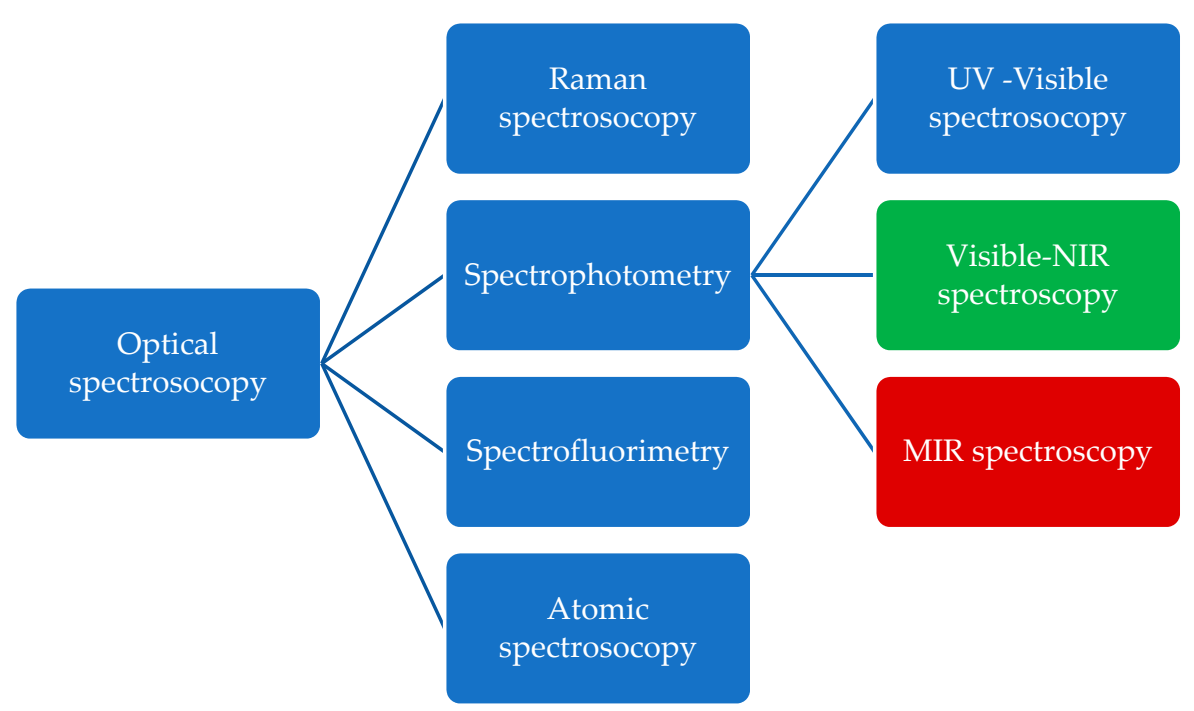

Figure 3. Optical spectroscopic techniques for milk quantitative and qualitative analysis.

Despite similarity in the background physical principles, analytical approaches, methods, and equipment for the spectral analysis of milk strongly differ in different spectral regions (UV, visible, NIR, MIR) and should be discussed separately. 


\subsection{UV-Visible Spectroscopy}

In the UV and the short-wavelength part of the visible region (below $500 \mathrm{~nm}$ ) characteristic electronic absorption of the whey proteins, fats, and some vitamins could be detected in diluted milk samples, while water is virtually transparent up to $900 \mathrm{~nm}$. This region is not often used for milk spectrophotometric analysis because of very intensive light scattering on the casein micelles and the necessity of sample dilution and pretreatment; the rare examples include the methods for determination of casein [54] and fat [56]. Some scattering-based techniques for fat and protein spectroscopic determination [64-67] exploit the longer wavelengths part of the visible spectrum often along with the short-wavelengths part of the NIR region (below $1100 \mathrm{~nm}$ ). The chief advantage of this approach is the possibility to develop cheap, portable, and easy-to-use analytical devices with CCD or CMOS silicon photodetectors.

\subsection{MIR Spectroscopy}

The MIR region is the most relevant for the spectral analysis of milk, since strong characteristic absorption bands associated with fundamental vibrational and rotational stretching modes of the main milk constituents molecules, including proteins, saccharides, fats, etc., are manifested in this part of the optical spectrum. At the same time background scattering on the milk particles is not so prominent because the ratio of the fat globules and casein micelles sizes to the working wavelengths is much lower than in the NIR region. Analytical methods based on MIR spectroscopy have been used for the laboratory testing of milk since sixties [68] and are well established now [69]. Novel approaches are constantly developing $[50,69,70]$ because this technique gives the most precise and detailed information about sample chemical composition; some examples of the most remarkable applications of MIR spectroscopy for the analysis of milk are summarized in the Table 5.

Because milk is an extremely complicated multicomponent scattering medium the straightforward determination of the constituents' concentrations from the intensity (or area) of the characteristic absorption peaks in spectra according to the classical Beer-Lambert law is impossible in most cases. Therefore, various multivariate chemometrics algorithms for spectral calibration and data analysis are applied: Partial Least Square Regression (PLS) and Discriminant Analysis (PLS-DA), Principal Component Regression (PCR), Principal Component Analysis (PCA), Artificial Neural Networks (ANN), Soft Independent Modeling of Class Analogy (SIMCA), Multivariate curve resolution alternating least square (MCR-ALS), etc. [71,72].

It is very important to mention that MIR spectroscopy is an immensely powerful tool not only for the quantitative determination of the basic milk constituents or residual amounts of antibiotics and disinfectants (see Table 5), but also widely used for detecting milk adulteration, when original proteins and fats are replaced with vegetables products, or foreign, often dangerous substances (sucrose, starch, urea, melamine, formalin, etc.) are deliberately and illegally added to milk and other dairy products by fraudsters to extend the shelf life or falsely increase the claimed protein and fat content. 
Table 5. Applications of MIR spectroscopy for the analysis of milk.

\begin{tabular}{|c|c|c|c|c|c|}
\hline Measurement Technique & Chemometrics & Spectral Range & $\begin{array}{l}\text { Milk Constituents/ } \\
\text { Adulterants }\end{array}$ & $\begin{array}{c}\text { Accuracy/ } \\
\text { Detection Limit } 1\end{array}$ & Reference \\
\hline FTIR/ATR & PLS, PCR, ANN & $\begin{array}{l}1600-1500 \mathrm{~cm}^{-1} \\
1100-1050 \mathrm{~cm}^{-1}\end{array}$ & proteins & $0.08-0.20 \%$ & {$[62]$} \\
\hline FTIR/ATR & PLS, PCR & $\begin{array}{c}3600-2800 \mathrm{~cm}^{-1} \\
1800-400 \mathrm{~cm}^{-1}\end{array}$ & total protein content, whey protein & $4 \% ; 8 \%$ (relative) & [73] \\
\hline FTIR/ATR & PLS, PCR & $4000-600 \mathrm{~cm}^{-1}$ & protein, fat, lactose, total solids & - & [63] \\
\hline FTIR/ATR & PCR, PLS, SIMCA & $1025 \mathrm{~cm}^{-1}$ & formalin & $0.5 \%$ & [74] \\
\hline FTIR/ATR & PCR, PLS, SIMCA & $996,1052 \mathrm{~cm}^{-1}$ & sucrose & $0.5 \%$ & [75] \\
\hline FTIR/ATR & PLS & $5000-900 \mathrm{~cm}^{-1}$ & protein fractions & - & [76] \\
\hline FTIR/ATR & PCA & $1700-600 \mathrm{~cm}^{-1}$ & milk species discrimination & - & [77] \\
\hline FTIR/ATR & $\begin{array}{l}\text { PLS, OPLS, Poly-PLS, } \\
\text { ANN }\end{array}$ & $3850-450 \mathrm{~cm}^{-1}$ & melamine & $1 \mathrm{ppm}$ & [78] \\
\hline FTIR/ATR & PLS & $4000-600 \mathrm{~cm}^{-1}$ & $\begin{array}{l}\text { water, starch, sodium citrate, } \\
\text { formaldehyde, sucrose }\end{array}$ & $0.5 \%$ & [79] \\
\hline FTIR/ATR & PCR, PLS, SIMCA & $4000-550 \mathrm{~cm}^{-1}$ & tetracycline & $10 \mu g / L$ & [80] \\
\hline FTIR & PLS-DA & $5000-925 \mathrm{~cm}^{-1}$ & mastitis detection & - & [81] \\
\hline
\end{tabular}

${ }^{1}$ Absolute errors of determination for the concentrations of components (in \%) are presented if not specified otherwise; detection limits are in italic. 
Fourier transform infrared (FTIR) spectrometers are usually used for the analysis of milk and dairy products in the MIR region; highly specialized platforms are available on the market, for example MilkoScan ${ }^{\circledR}$ series by FOSS (Hillerød, Denmark). The main obstacle for wider implementation of this technique is strong MIR water absorption [82]; so very thin optical cuvettes or, which is more preferable, attenuated total internal reflectance (ATR) accessories have to be used [62]. The main element of an ATR accessory is an optically dense IR crystal with a high refractive index which is simultaneously transparent in a working spectral range (Figure 4). An incident IR beam travels through the crystal and undergoes multiple total internal reflections. The surface of the crystal is in direct contact with a liquid medium where an evanescent electromagnetic wave propagates along the border. In regions of the spectrum where the liquid absorbs electromagnetic energy of the evanescent wave the IR beam in the crustal is attenuated.

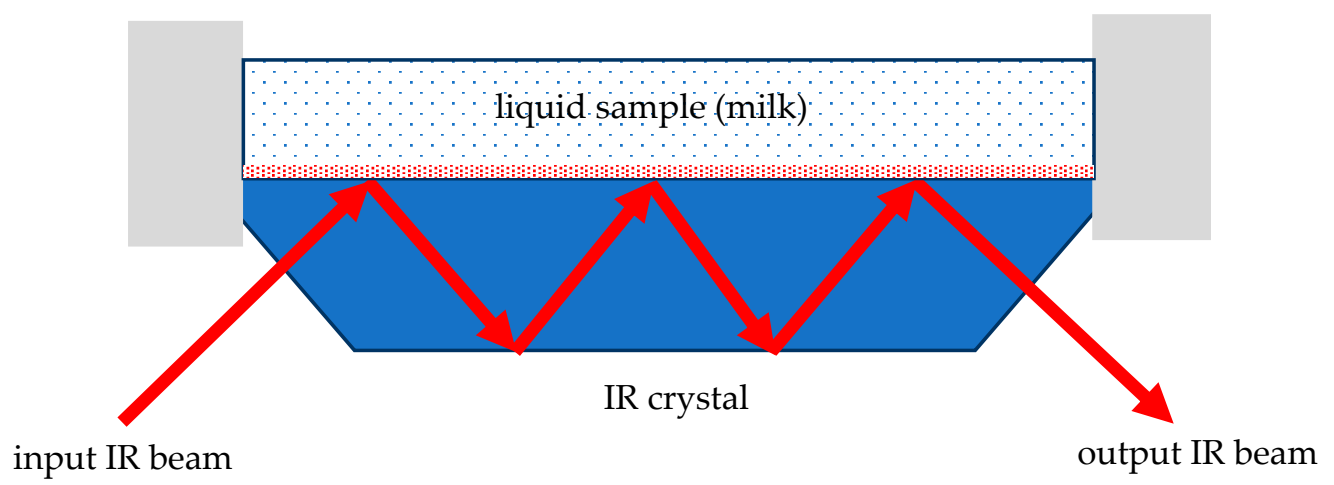

Figure 4. Measuring MIR absorption spectra using ATR setup.

Because the penetration depth of the evanescent wave is limited to a few micrometers, IR radiation interacts with the liquid sample in a very thin near-surface layer. As a consequence, the spectra are very sensitive to the presence of fat globules or fat biofilms in the boundary layer that forms at the interface between the milk and the crystal which serves both as radiation waveguide and sensing element [83]. In combination with such factors as high-cost spectral equipment, complicated maintenance, cleaning, calibration, and sample preparation procedures, this fundamental limitation makes FTIR/ATR spectroscopy almost exclusively off-line, laboratory technique not suitable for real-time in-line monitoring in milking machines on farms or milk processing equipment on production facilities [65].

\subsection{Near-Infrared (NIR) and Visible Spectroscopy}

In the NIR range characteristic absorption bands corresponding to the overtones and combination vibrations of proteins, lactose, fat, and water molecules are manifested (see Table 6), but these bands are weaker than in the MIR region and harder to distinguish on the background of highly intensive light scattering on the milk particles-the fat globules and casein micelles. The NIR spectra of the bulk scattering coefficient and the scattering anisotropy factor strongly depend on the particle size distribution which can vary in each sample of milk [50]. It means that samples with equal fat and protein content, but different particle size distributions have different spectral transmittance and reflectance, which makes extracting information about sample composition from the spectral data a complicated task, especially for raw, unhomogenized milk [65].

From the other side, weaker than in MIR, water absorption, especially in the visible and the short-wavelength part of the NIR region allows using longer optical path flow-through cuvettes (up to $10 \mathrm{~mm}$ ) suitable for in-line measurements. Another advantage of NIR techniques is the possibility to employ more affordable and robust multichannel detectors-based spectral instruments with no moving parts. Despite some lack of sensitivity and selectivity, less reliable and more specific calibration compared to MIR spectroscopy, NIR techniques are now leading in milk analysis. 
Different approaches and measuring schemes (Figures 5 and 6) are used for the registration of the NIR spectra of milk, including collimated transmission (CT) [84], diffuse transmission (DT) [64], diffuse reflection (DR) [85], backscattering (BS) [86].

Table 6 summarizes the applications of NIR technologies for the quantitative and qualitative determination of the main milk constituents (crude protein, casein, fat, lactose), comatic cells count, and common adulterants reported in the selected papers.

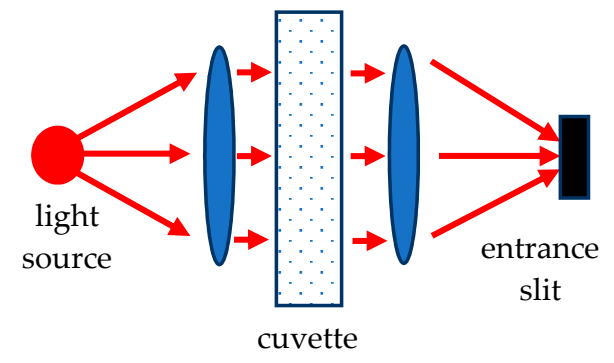

(a)

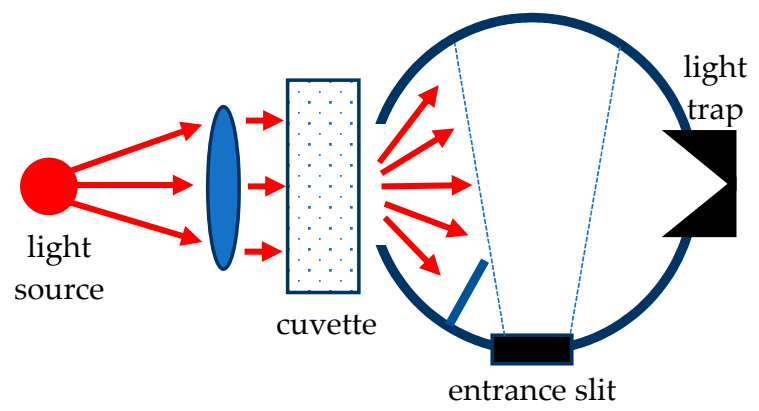

(b)

Figure 5. Measuring collimated transmission (a) and diffuse transmission (b).

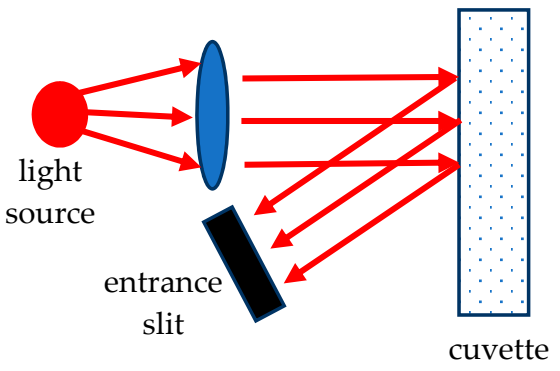

(a)

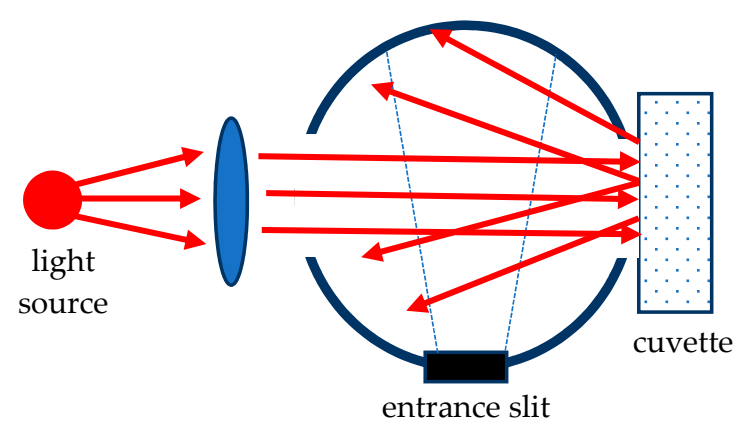

(b)

Figure 6. Measuring backscattering (a) and diffuse reflection (b). 
Table 6. Applications of NIR spectroscopy for the analysis of milk.

\begin{tabular}{|c|c|c|c|c|c|}
\hline Measurement Technique & Chemometrics & Spectral Range & $\begin{array}{l}\text { Milk Constituents/ } \\
\text { Adulterants }\end{array}$ & $\begin{array}{c}\text { Accuracy/ } \\
\text { Detection Limit } 1\end{array}$ & Reference \\
\hline DT & PLS, PCR & $800-2500 \mathrm{~nm}$ & $\begin{array}{l}\text { protein, fat, lactose, } \\
\text { total solids }\end{array}$ & $\begin{array}{c}8.2 \% ; 9.3 \% ; 5.4 \% ; 2.2 \% \\
\text { (relative) }\end{array}$ & [63] \\
\hline DR & PLS & $400-995 \mathrm{~nm}$ & fat, protein & $0.10 \% ; 0.008 \%$ & [64] \\
\hline DT & PLS & $400-1100 \mathrm{~nm}$ & fat, protein & $0.08 \% ; 0.04 \%$ & [65] \\
\hline $\mathrm{CT}$ & PLS & $400-1000 \mathrm{~nm}$ & fat, protein & $0.05 \% ; 0.03 \%$ & [66] \\
\hline DT & PLS & $400-1100 \mathrm{~nm}$ & fat, protein & $0.09 \% ; 10 \%$ & [67] \\
\hline DT & PLS & $400-2500 \mathrm{~nm}$ & fat, protein, lactose & $0.04 \% ; 0.13 \% ; 0.13 \%$ & [84] \\
\hline $\mathrm{DR}$ & PLS & $400-1700 \mathrm{~nm}$ & fat, protein, lactose & $0.05 \% ; 0.1 \% ; 0.18 \%$ & {$[84]$} \\
\hline DT & PLS & 1100-2500 & fat, protein, casein & $0.05-0.07 \%$ & [87] \\
\hline DT & PLS & $\begin{array}{l}1100-2500 \mathrm{~nm} \\
700-1100 \mathrm{~nm}\end{array}$ & fat; protein; lactose & $\begin{array}{c}0.11 \% ; 0.12 \% ; 0.09 \% \\
0.19 \% ; 0.19 \% ; 0.1 \%\end{array}$ & {$[88]$} \\
\hline DR & PLS & $851-1649 \mathrm{~nm}$ & fat, protein, lactose & $0.03 \%, 0.07 \%, 0.09 \%$ & [89] \\
\hline DT & PLS & $400-1100 \mathrm{~nm}$ & fat & $0.12 \%$ & [90] \\
\hline DR & MCR-ALS, SIMCA & $1000-2500 \mathrm{~nm}$ & melamine; sucrose & $\begin{array}{c}0.14 \%(0.8-2 \%) ; 0.08 \% \\
(1-3 \%)\end{array}$ & [91] \\
\hline DR & PCA, PLS & $700-2500 \mathrm{~nm}$ & sucrose & $0.04 \%$ & [92] \\
\hline $\mathrm{CT}$ & PCA, PLS & $1000-2500 \mathrm{~nm}$ & urea & $0.48 \%$ & [93] \\
\hline FTIR/DT & $\begin{array}{c}\text { PLS, OPLS, Poly-PLS, } \\
\text { ANN }\end{array}$ & $1110-2500 \mathrm{~nm}$ & melamine & $1 \mathrm{ppm}$ & [78] \\
\hline DT & PLS & $700-1100 \mathrm{~nm}$ & somatic cells count & $0.3 \operatorname{LogSCC}$ & [94] \\
\hline
\end{tabular}

${ }^{1}$ Absolute errors of determination for the concentrations of components (in \%) are presented if not specified otherwise; detection limits are in italic. 
In contrast to the off-line milk analyzers based on FTIR spectrometers working in the MIR spectral region, NIR technology allows developing portable devices for fast on-farm milk quality control [95] and analytical solutions for in-line applications in milking robots [96] and automated milking systems [97]. Authors claim that such devices can determine the concentrations of three major milk constituents (fat, protein, and lactose) and somatic cells count with accuracy which is quite acceptable for practical use.

\subsection{Atomic Spectroscopy, Raman Spectrosocopy, Fluorescent Spectrosocopy}

Besides the above-mentioned spectrophotometric methods based on measuring molecular absorption and elastic scattering of optical radiation, spectroscopic techniques that utilize different optical phenomena are also used for milk analysis and quality control, though not so often.

In analytical chemistry, atomic spectroscopy is considered to be the most widespread method for elemental analysis; when applied to milk and dairy products it is mainly used for the determination of macroelements ( $\mathrm{Ca}, \mathrm{P}, \mathrm{Mg}, \mathrm{K}$ ) and microelements ( $\mathrm{P}, \mathrm{Fe}, \mathrm{Zn}, \mathrm{Se}, \mathrm{Al}, \mathrm{Cd}, \mathrm{Cu}, \mathrm{S})$, including toxic heavy metals $(\mathrm{Cd}, \mathrm{Pb})$. Various techniques are employed: atomic absorption spectroscopy with prior atomization [98], inductively coupled plasma atomic emission spectrophotometry [99,100].

Raman spectroscopy has long been used for the quality control and the quantitative analysis of powdered milk and baby formula and to screen samples adulterated with whey and melamine. It is a very capable and convenient method, because Raman spectra can be collected extremely fast, without any special sample preparation, and even from samples in glass and polymer packaging [101]. The main obstacle for the application of Raman analysis for liquid milk and other dairy products with high humidity is a weak signal from the main milk constituents on the background of very intensive water bands. Despite this problem modern chemometrics approaches have been successfully used for extracting from the Raman spectra of milk information about the concentrations of fat, proteins, lactose, antibiotics, and adulterants (melamine) [102]. Raman spectroscopy are even considered as a perspective on-line analytical method [103].

Molecular fluorescence spectroscopy is one of the most sensitive and highly selective spectroscopic methods, which can detect extremely low amount of chemical substances. In milk industry it is used for the determination of vitamins, fatty acids [104], residual amounts of antibiotics [105], and identification of different milk species in dairy products [106].

\subsection{Prospects for the Further Development of Optical Methods and New Devices for Milk Analysis}

The main leading trend in the optical spectroscopy of milk and dairy products is developing affordable, portable, on-site or in-line devices, which can be used outside of a laboratory or even incorporated in milking robots or processing equipment, for the monitoring of milk quality in real-time, either on milking-farms or production facilities. The most promising results so far have been achieved in the NIR technologies, even with conventional spectral equipment, mainly because of the implementation of sophisticated chemometrics algorithms such as artificial neural networks.

The other acute problem in milk analysis is the detection of as many known adulterants as possible. Despite constant improving of the calibration and prediction algorithms it is not always possible even by FTIR spectroscopy because of the inherent limitations of optical spectroscopic techniques [107]. Combination of several different approaches, for example spectrophotometry and acoustic analysis, may be a solution here.

\section{Ultrasound Approaches and Techniques for Milk Analysis}

Ultrasound techniques are well-developed instruments used for non-destructive, accurate, and non-invasive measurements [108,109]. In the dairy industry, ultrasound is widely used both for non-destructive monitoring of the quality and parameters of milk [37,110-118], and in the ultrasonic processing of dairy products $[110,119,120]$. In the first case, low-intensity ultrasound (less than $1 \mathrm{~W} / \mathrm{cm}^{2}$ ) is used at frequencies above $100 \mathrm{kHz}$, which is a non-destructive instrument for milk characterization. 
In the second case, high-intensity ultrasound (above $10 \mathrm{~W} / \mathrm{cm}^{2}$ ) is mostly used in the $20-100 \mathrm{kHz}$ frequency range, which is destructive for milk sample: it modifies the properties of milk and is used for the ultrasound treatment at different stages of dairy products processing. In this review, we are interested only in methods of low-power non-destructive ultrasonic characterization of milk.

Ultrasound spectrometry offers the ability to characterize dairy products excluding special preparation or disruption of the liquid sample. In addition, ultrasound methods are of interest for monitoring processes in real time.

\subsection{Acoustic Properties of Milk}

Acoustic measurement techniques can provide data about protein [121] and fat [113] content, physiochemical changes of milk with time [122], size distribution of air and fat droplets [123], content of contaminants [112].

When an acoustic wave propagates through a liquid sample, its amplitude decreases, and the phase changes because of the interaction with liquid medium and its dispersed filler. The decline in ultrasound intensity is commonly called attenuation. The phase links to the velocity of propagation of sound through a sample. The variations of sound velocity and attenuation are governed by the physicochemical features of liquid medium and its ingredients. By measuring changes in these acoustic parameters, specific information about the properties of a liquid sample can be accessed. Thus, the thermo-acoustic, physical, and chemical properties of milk can be obtained by measuring ultrasound speed and attenuation. These measurements can be carried out by such methods as transmission, pulse-echo and interferometer techniques (Figure 7). An alternative microbalance approach to acoustic measurements allows access to viscosity and density of milk via measuring of additional mass load of resonant sensor. The analysis and interpretation of acoustic measurements can be done in two steps. The first step is purely phenomenological and involves determination of the ultrasound parameters (speed of sound and attenuation, or viscosity and density) of milk sample. The second step requires the use of model to describe the real milk as a complex multiphase polydisperse system. By solving inverse problems on the basis of appropriate models, it is possible to determine the content of various ingredients in milk and their size information. Such calculations can be done using models of ultrasound attenuation [123] and velocity [124] in dispersed liquids and emulsions.

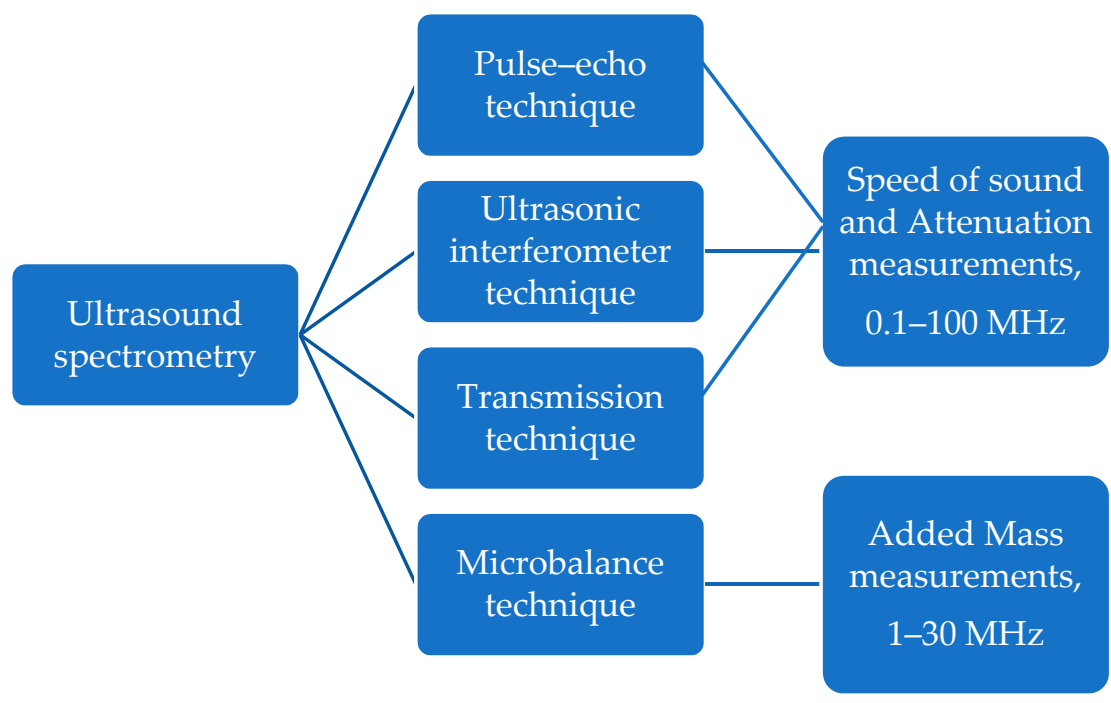

Figure 7. Ultrasound techniques for milk quantitative and qualitative analysis.

The speed of sound can provide some specific information about the composition of a liquid. Speed of sound is a collective value. The simplest mixing rule for sound velocity has been proposed 
by [125] and fits well with experimental data in liquid mixtures. Molecule interactions gives to excess Gibb's energy to an ideal mixture, and this affects in an excess compressibility and an excess volume [126]. The speed of sound contains information about the nature of interactions between molecules, because it depends on changes in the shape of molecules and on the type of interaction potentials between the components of liquid mixture [127]. The speed of sound in suspensions and emulsions was studied in detail in [124]. The sound velocity is very sensitive to milk chemistry content and temperature. It is the most suitable parameter for studying milk features on a molecular scale, that is, with characteristic dimensions in angstroms. The speed of sound changes from 1000 to $2000 \mathrm{~m} / \mathrm{s}$ for a variety of dairy products. For dilute milk, it is about $1500 \mathrm{~m} / \mathrm{s}$, close to water sound velocity at room temperature.

Attenuation of ultrasound propagating through a heterogeneous system is the sum of scattering and absorption. Particle scattering redirects energy of ultrasound wave out of the propagation line. Absorption converts ultrasonic energy into heat because of the interaction effects between the ultrasonic wave and particles and medium. The propagation of acoustic waves through the milk medium is mainly of a thermodynamic character. Big droplets can serve as scattering centers. Submicron particles in milk only absorb ultrasound. Absorption in milk can be divided into so-called internal attenuation and thermal attenuation. The first is measured directly. The second is associated with differences in thermo-mechanical properties between particles and a liquid medium, whereby the particles and liquid expand in ultrasonic field in different ways, creating a temperature gradient at the particle-liquid interface, as a result of which the ultrasonic energy at this interface is converted into heat $[123,128]$. Thermal part of attenuation in a liquid medium depends on thermal conductivity, thermal expansion, and heat capacity. The total value of the thermal part of attenuation of the multiphase polydisperse liquid depends on these three thermo-mechanical parameters for each component as well as the particle distribution by sizes [123]. Ultrasound attenuation is not good enough to reflect changes in chemical, ionic, and molecular milk composition, but it is sensitive to particles present in milk. Attenuation perceives changes in nanometre-micrometre size level and is suitable for characterizing liquid features associated with inhomogeneity and phase composition of a disperse liquid system [113,123]. Milk can be modelled as a liquid composition of spherical fat droplets of approximately spherical shape in an aqueous solution of proteins and sugars [123,124,129]. Knowing the corresponding physical properties of the constituent milk ingredients, fat particles size distribution in milk can be determined from measurements of attenuation [123]. Attenuation in milk can vary very widely depending on the frequency. In water the attenuation rises with frequency up to $0.2 \mathrm{~dB} / \mathrm{cm}$ per $\mathrm{MHz}$ at $100 \mathrm{MHz}$. In milk, depending on the fat content, the attenuation can vary from 0.4 to $0.7 \mathrm{~dB} / \mathrm{cm}$ per $\mathrm{MHz}$ for $100 \mathrm{MHz}$ and from 0.1 to $0.4 \mathrm{~dB} / \mathrm{cm}$ per $\mathrm{MHz}$ for $2 \mathrm{MHz}$. For comparison, for butter and margarine, the attenuation increases from 2 to $7 \mathrm{~dB} / \mathrm{cm}$ per $\mathrm{MHz}$ as the frequency increases from $2 \mathrm{MHz}$ to $100 \mathrm{MHz}$ [113].

Milk density is close to the density of water. Normal milk density ranges from 1027 to $1032 \mathrm{~kg} / \mathrm{m}^{3}$, with an average of $1030 \mathrm{~kg} / \mathrm{m}^{3}$. The density of milk is higher if it contains more sugar, proteins, and minerals, and lower, with an increase in fat [130]. Density can reflect falsification: decreases with water addition and increases with skimming or diluted with skim milk. For example, a density of $1028 \mathrm{~kg} / \mathrm{m}^{3}$ indicates natural milk, $1027 \mathrm{~kg} / \mathrm{m}^{3}$ means suspicious milk, $1027 \mathrm{~kg} / \mathrm{m}^{3}$ and below indicates falsified milk with water, more than $1031 \mathrm{~kg} / \mathrm{m}^{3}$ means suspicion of dilution backwards. The addition of water to milk causes a decrease in density of approximately $3 \mathrm{~kg} / \mathrm{m}^{3}$ for every $10 \%$ water added. It is characteristic that if the fat is removed from the milk and the same amount of water is added, then the density does not change, and such falsification can only be detected by determining the amount of fat in the milk [22].

Viscosity of milk is understood as the internal friction of liquid layers during their relative movement, which depends on the adhesion forces between the molecules. The viscosity of milk is influenced by emulsified (fats) and colloid-soluble particles (casein), the state of whey proteins, technological modes of milk processing, causing changes in the state of aggregation of its components, etc. [131]. The viscosity of milk and dairy products strongly depends not only on the 
composition, but also on the temperature [132]. An increase in temperature leads to an increase in the speed of Brownian motion (random motion [133]) of solution molecules, a weakening of the interaction forces between them, and as a consequence, a decrease in viscosity. However, if the temperature exceeds the coagulation point of whey proteins, the viscosity of these products begins to increase again. This is due to a decrease in the degree of dispersion of whey proteins caused by their thermal denaturation and aggregation [134]. Typical values of milk viscosity are given in Table 2.

Techniques for measuring the above acoustic properties of milk are briefly discussed below.

\subsection{Transmission Technique}

Figure 8a shows in a simplified way the idea of the transmission measurement method. To the left and to the right of the cuvette with the liquid sample, two piezoelectric transducers are located at the same level, opposite to each other. The first acts as a transmitter, and the second as a receiver of an ultrasound waves. The transmitter sends an ultrasonic wave with a certain frequency and amplitude into the liquid-filled cuvette, and the receiver gets a signal weakened in intensity and changed in phase as a result of the wave propagation through the liquid sample and the interaction between ultrasound wave and liquid medium and its dispersed filler. A piezoelectric receiver converts this ultrasonic signal into an electrical one, which is then compared with the input signal. The result of such a comparison makes it possible to determine the values of speed of sound and attenuation in a liquid sample, according to the equations $[108,135]$ :

$$
V=x / t ; A_{\text {out }}=A_{\text {in }} \exp (-\alpha x),
$$

where $V$ is the speed of sound; $\alpha$ is attenuation; $x$ is the traveling distance; $t$ is the traveling time of the wave; $A_{\text {in }}$ and $A_{\text {out }}$ are the amplitudes of ultrasound wave at the beginning and at the end of the traveling distance. For the transmission approach (Figure 8a) $x=L$.

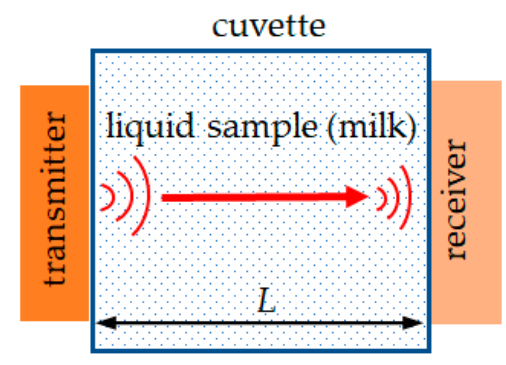

(a)

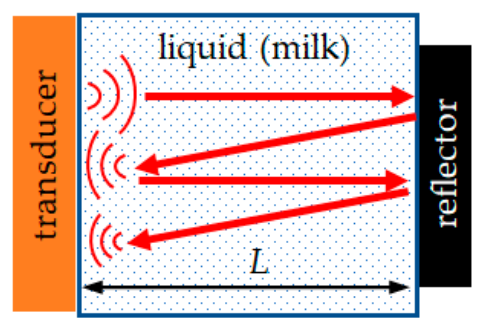

(b)

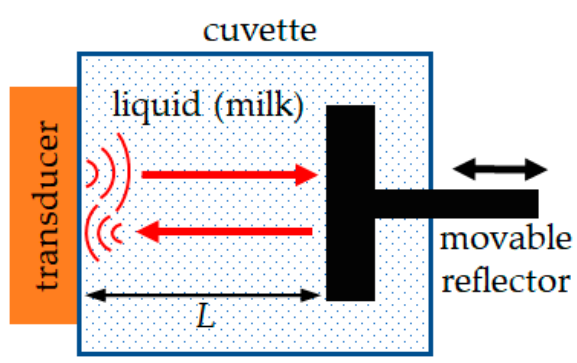

(c)

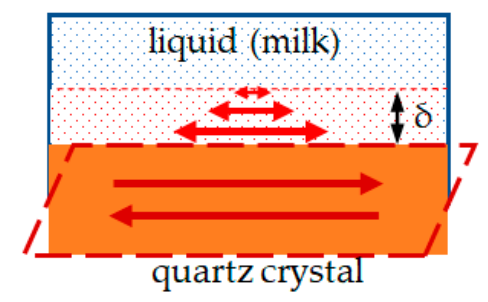

(d)

Figure 8. Ultrasound measuring approaches: simplified illustrations of transmission (a), pulse-echo (b), interferometer (c) and quartz crystal microbalance (d) techniques.

Sound velocity and attenuation measurements can be made over a wide frequency range, typically for milk in the 1 to $100 \mathrm{MHz}$ range.

The most informative frequency range for detecting fat in milk is from 40 to $50 \mathrm{MHz}$ [113]. Relatively big particles, such as air droplets in milk, can be detected by measuring the attenuation 
spectrum at low frequencies up to $10 \mathrm{MHz}$. Small particles down to $5 \mathrm{~nm}$ can be detected by studying and interpretation of the attenuation spectra in the higher frequency part of the spectrum up to $100 \mathrm{MHz}$ [123]. For a sufficiently accurate control of the fat particle size distribution in milk, an attenuation measurement accuracy of level about $0.01 \mathrm{~dB} / \mathrm{cm}$ per $\mathrm{MHz}$ is required [113].

The accuracy of sound velocity measurements is limited by the accuracy of temperature control. A $1{ }^{\circ} \mathrm{C}$ change in temperature leads to a change in the velocity of sound in water by $2.4 \mathrm{~m} / \mathrm{s}$, while maintaining a uniform temperature of the liquid sample with an accuracy less than $0.01{ }^{\circ} \mathrm{C}$ is impossible.

The transmission method has been used by various researchers to determine the water content, fat content [113], particle size distribution [123], and various chemical compounds [113], melamine [114], microorganisms [136] in milk.

\subsection{Pulse-Echo Technique}

In a pulse-echo method $[110,137]$, the only one piezoelectric transducer is used (see Figure $8 b$ ). It is both a transmitter and a receiver of the ultrasonic signals. On the opposite side of the cuvette with a liquid sample, there is a reflector. The wall of the cuvette can act as a reflector, while for good reflection it is important to reach a high acoustic contrast and low acoustic losses at the liquid-wall interface. The pulsed ultrasound wave is directed from the transducer to the opposite wall of the cuvette, reflected from it, and returns to the transducer with weakened intensity. The wave partially reflected from the transducer travels the same path again and returns to the transducer as a second echo. Knowing the travel time of the wave and the distance, it is possible to calculate the speed of sound and attenuation based on Equation (2), only in this case, unlike the transmission method, the travel distance $x$ is equal to $2 L$ for the first echo and $4 L$ for the second one. Also, when using Equation (2) to calculate attenuation, it is necessary to take into account multiple reflections and the respective reflection coefficients at the interfaces.

Pulse-echo technique has been used to determine the water content, carbohydrates, and total fat content, fat globular, and casein micelles sizes distribution in milk [110,124,137].

\subsection{Ultrasonic Interferometer Technique}

At first glance, the ultrasonic interferometer technique is very close to the previous approach, but in reality, it has differences both in the method of collecting raw data, in the approach to their analysis, and in sensitivity to changes in the speed of sound and attenuation. An ultrasonic interferometer uses a single transducer that serves both transmitter and receiver roles. On the opposite side there is a movable reflector (Figure 8c) that allows profiling the distance at which standing acoustic waves are generated in the liquid sample because of the interference of the incident and reflected waves. When the distance between transducer and reflector changes, the intensity oscillations are measured, corresponding to the maxima and minima of the ultrasonic wave along its propagation path with a step of the half wavelength. Description of devices, principles of use, and improvements of the ultrasonic interferometer technique can be found in [138-140]. Furthermore, some devices of the ultrasonic interferometer include optical diffraction, which allows expanding its analytical capabilities [141]. Examples of using an ultrasonic interferometer for milk analysis are given in [111,142].

\subsection{Microbalance Technique}

Acoustic resonant sensor principles are broadly used as biochemical sensors. They are typically understood to convert a surface mass change into a frequency change of a resonant device. They are therefore often called microbalance with the quartz crystal microbalance (QCM) being its most prominent sensor. However, a resonance sensor is far more than a mass balance. Shear bulk acoustic resonators are commonly used for biosensing because of low in-liquid radiation losses. This allows to keep relatively high quality factor of the resonant sensor even while interfacing viscous liquids. QCM is a recognized technology that is used to detect interactions at the surface [143]. Excited at a 
shear bulk vibration mode, its resonant frequency shifts in accordance with interface loading. For milk characterization, QCM is commonly used to detect proteins $[121,144,145]$.

The QCM measurements are based on a frequency shift $(\Delta f)$ detection from the fundamental resonant frequency $\left(f_{0}\right)$ of quartz resonator when it is loaded by a small additional mass $(\Delta m)$ per area of electrode $(A)$, according to the equation:

$$
\Delta f=-K \cdot f_{0}^{2}(\Delta m / A)
$$

where $K$ is a constant and depends on the properties of quartz crystal and its cut.

Small mass and high Q-factor of the resonator give access to a mass detection limit $\Delta m / m_{\text {res }}$ of $10^{-6}$ to $10^{-9}$ with $\Delta m$ and $m_{\text {res }}$ being the added mass and resonator mass per unit area, respectively.

When a quartz crystal sensor is in direct contact with a liquid, the shear wave penetrates into it to a small depth and the frequency shift is determined by the acoustic properties of the near-surface liquid with the thickness of $\delta=(\eta / \pi \rho f)^{1 / 2}$ (Figure $8 \mathrm{~d}$ ), where $\eta$ and $\rho$ are the liquid viscosity and density. For reliable separate measurements of liquid sample viscosity and density, in [143] a method for comparing the results of measuring a liquid using smooth and corrugated electrodes of QCM was proposed. The respective frequency shifts for a smooth- $\left(\Delta f_{1}\right)$ and corrugated-surface $\left(\Delta f_{2}\right)$ QCM liquid sensors are given as [143]:

$$
\Delta f_{1}=-c_{1} \sqrt{\rho \eta} ; \quad \Delta f_{2}=-c_{1} \sqrt{\rho \eta}-c_{2} h \rho,
$$

where $c_{1}$ and $c_{2}$ are constants, $h$ is the depth of the grooves on the corrugated surface of QCM electrode.

Some modern QCM biosensors use a sensitive or recognition layer to enhance sensitivity and selectivity for specific ingredients in liquid sample. Such QCM biosensors with specially prepared sensitized surfaces have been used to detect specific proteins in milk [144,145].

Table 7 summarizes information about ultrasonic measurements of milk by various research groups.

\subsection{Prospects for the Further Development of Ultrasound Methods and New Devices for Milk Analysis}

New promising directions for the development of milk characterization can become microfluidic concepts, phononic crystals concepts, and a combination of acoustic and optical approaches in one device.

Microfluidic technologies may be of interest for separating milk ingredients using acoustophoresis and other methods. Pre-separation of particles based on their differences in size and other physical properties allows for more accurate analysis at a later stage. Up to now, various microfluidic devices have been developed to separate and characterize suspensions and emulsions [112,129]. The acoustofluidic separation can become a powerful instrument for accurate milk analysis.

Improving existing and developing new microfluidic sensor devices involves the use of phononic crystals with liquid-filled cavities [146-148]. Phononic crystals can manipulate and tailor elastic and acoustic wave propagation, can create dynamically resonant metastructures. Phononic crystal designs can be scaled to meet given real object dimensions. Resonance frequency and bandwidth are highly sensitive to geometric and material parameters, specifically speed of sound and sound attenuation. High resolution requires high- $Q$ resonators. Fabrication of phononic crystal and resonant sensor structures with high Q-factor is a challenging but realistic task. Recent studies [146-148] show that the use of phononic crystals can improve the resolution and isolation of responses from liquid resonances. The unique combination of the properties and concepts of phononic crystals, resonant sensors, ultrasonic measurement, and acoustofluidic methods can lead us to a new generation of high-sensitive and high-resolutive liquid sensor devices. 
Table 7. Applications of ultrasound techniques for the analysis of milk.

\begin{tabular}{|c|c|c|c|c|c|}
\hline Measurement Technique & Measured Parameters & $\begin{array}{c}\text { Frequency Range/Centre } \\
\text { Frequencies }\end{array}$ & $\begin{array}{l}\text { Milk Constituents/ } \\
\text { Adulterants }\end{array}$ & $\begin{array}{c}\text { Accuracy/ } \\
\text { Detection Limit }{ }^{1}\end{array}$ & Reference \\
\hline Transmission & attenuation & $40-50 \mathrm{MHz}$ & fat & $0.2 \%$ & [113] \\
\hline Transmission & attenuation & $\begin{array}{l}1-10 \mathrm{MHz} \\
1-100 \mathrm{MHz}\end{array}$ & $\begin{array}{l}\text { particle size distribution, } \\
\text { particle sizes }\end{array}$ & $\begin{array}{c}\text { single } 1-\mu \mathrm{m} \text { particle per } 100,000 \\
\text { particles with size } 100 \mathrm{~nm}, \\
\text { from } 5 \mathrm{~nm}\end{array}$ & [123] \\
\hline Transmission & attenuation & $0.5,0.7 \mathrm{MHz}$ & $\mathrm{pH}$ & - & [122] \\
\hline Transmission & attenuation & $0.8 \mathrm{MHz}$ & microorganisms & - & [136] \\
\hline Transmission & sound speed & $1-100 \mathrm{MHz}$ & $\begin{array}{l}\text { carbohydrates, } \\
\text { mineral salts }\end{array}$ & $10^{-4} \mathrm{~mol} / \mathrm{L}$ & [113] \\
\hline Transmission & sound speed & $4 \mathrm{MHz}$ & melamine & $6 \%$ & [114] \\
\hline Pulse-echo & sound speed & $1 \mathrm{MHz}$ & carbohydrates & $0.2 \%$ & [137] \\
\hline Pulse-echo & $\begin{array}{l}\text { sound speed and } \\
\text { attenuation }\end{array}$ & $1-10 \mathrm{MHz}$ & $\begin{array}{l}\text { fat globules, } \\
\text { casein micelles }\end{array}$ & - & $\begin{array}{l}{[137],} \\
{[124]}\end{array}$ \\
\hline Interferometer & attenuation & $1 \mathrm{MHz}$ & dry matter & - & [112] \\
\hline Interferometer & attenuation & 3-99.5 MHz & $\begin{array}{l}\text { casein micelles size } \\
\text { distribution }\end{array}$ & $0.05 \mu \mathrm{m}$ & [142] \\
\hline QCM & mass & $5 \mathrm{MHz}$ & $\beta$-lactoglobulin & $0.4-0.9 \mathrm{mg} / \mathrm{m}^{2}$ & [121] \\
\hline QCM & mass & $30.8 \mathrm{MHz}$ & cortisol & $0.1 \mathrm{pg} / \mathrm{mL}$ & [144] \\
\hline QCM & mass & $10 \mathrm{MHz}$ & PSS 208 protein & $1 \mathrm{ppm}$ & [145] \\
\hline
\end{tabular}

${ }^{1}$ Absolute errors of determination for the concentrations of components; detection limits are in italic. 
The development of liquid sensor devices that combine the advantages of optical and acoustic methods are carried out both on the basis of traditional methods (like ultrasonic interferometer include optical diffraction [141]) and using promising phononic-photonic crystals approaches [149].

\section{Conclusions}

The use of rapid methods for the analysis of the composition and falsification of dairy products has significant advantages over traditional chemical methods. These advantages include: high productivity and degree of automation, speed of measurements, minimal sample preparation, as well as the ability to determine a large number of parameters from the data of one experiment. But to create optimal analyzers for modern manufacturers, it is still necessary to solve such issues as the possibility of introducing the sensor into the milk pipeline, where it will have to take into account the complex polydisperse composition of milk and the heterogeneity of the flow. The analysis should be carried out in the shortest possible time, preferably in real time, and most importantly for manufacturers, it should be inexpensive.

Optical spectroscopy is an extremely powerful and versatile tool for the quantitative and qualitative analysis of milk composition. Not only the concentrations of the principal milk constituents (fat, protein, lactose) but somatic cells count, common adulterants, residual amounts of antibiotics and disinfectants, amino acid composition, and even milk species could be estimated by optical spectroscopic techniques.

Recent advances in chemometrics made possible more widespread use of NIR spectroscopy which allows developing and implementing spectral equipment for on-site or in-line monitoring of milk quality in real-time.

Optical methods are capable of detecting many types of milk adulteration, but not all of them; using optical spectroscopy in combination with other approaches, for example acoustic methods may greatly improve the analytical possibilities of this technique.

Ultrasound techniques are well-developed instruments used for non-destructive, accurate, and non-invasive measurements. Ultrasound spectrometry offers the ability to characterize dairy products excluding special preparation or disruption of the liquid sample. In addition, ultrasound methods are of interest for monitoring processes in real time.

Acoustic measurement techniques can provide data about protein and fat content, size distribution of air and fat droplets, physiochemical changes of milk with time, content of contaminants.

New promising directions for the development of milk characterization can become microfluidic concepts, phononic crystals concepts and a combination of acoustofluidic and optical approaches in one device.

Author Contributions: Section 2 was written by A.S.; Section 3 was prepared by G.K. and O.S.; Section 4 was written by N.M. and U.S. Final editing of manuscript was made by A.S. and N.M. All authors have read and agreed to the published version of the manuscript.

Funding: This research received no external funding.

Conflicts of Interest: The authors declare no conflict of interest.

\section{References}

1. Caroli, A.; Poli, A.; Ricotta, D.; Banfi, G.; Cocchi, D. Invited review: Dairy intake and bone health: A viewpoint from the state of the art. J. Dairy Sci. 2011, 94, 5249-5262. [CrossRef] [PubMed]

2. Rozenberg, S.; Body, J.-J.; Bruyère, O.; Bergmann, P.; Brandi, M.L.; Cooper, C.; Devogelaer, J.-P.; Gielen, E.; Goemaere, S.; Kaufman, J.-M.; et al. Effects of dairy products consumption on health: Benefits and beliefs-A commentary from the belgian bone club and the european society for clinical and economic aspects of Osteoporosis, Osteoarthritis and Musculoskeletal Diseases. Calcif. Tissue Int. 2016, 98, 1-17. [CrossRef] [PubMed]

3. Van Lieshout, G.A.A.; Lambers, T.T.; Bragt, M.C.E.; Hettinga, K.A. How processing may affect milk protein digestion and overall physiological outcomes: A systematic review. Crit. Rev. Food Sci. Nutr. 2020, 60, 2422-2445. [CrossRef] [PubMed] 
4. Willett, W.C.; Ludwig, D.S. Milk and Health. N. Engl. J. Med. 2020, 382, 644-654. [CrossRef] [PubMed]

5. Neumann, C.; Harris, D.M.; Rogers, L.M. Contribution of animal source foods in improving diet quality and function in children in the developing world. Nutr. Res. 2002, 22, 193-220. [CrossRef]

6. U.S. Department of Health and Human Services; U.S. Department of Agriculture. 2015-2020 Dietary Guidelines for Americans. 8th Edition. December 2015. Available online: https://health.gov/our-work/foodand-nutrition/2015-2020-dietary-guidelines/ (accessed on 30 January 2020).

7. Order of the Ministry of Health of the Russian Federation of August 19, 2016 No. 614 “On Approval of Recommendations on Rational Norms of Food Consumption that Meet Modern Requirements for Healthy Nutrition". Available online: https://static-2.rosminzdrav.ru (accessed on 7 May 2020).

8. Jenkins, T.C.; McGuire, M.A. Major Advances in Nutrition: Impact on Milk Composition. J. Dairy Sci. 2006, 89, 1302-1310. [CrossRef]

9. OECD-FAO Agricultural Development Forecast 2020-2029, for Commodities OECD-FAO Agricultural Outlook 2020-2029. Available online: https://stats.oecd.org/viewhtml.aspx?QueryId=98960\&vh=0000\&vf= $0 \& 1 \& i 1=\& l a n g=e n \#$ (accessed on 2 September 2020).

10. Dumuta, A.; Giurgiulescu, L.; Mihaly-Cozmuta, L.; Vosgan, Z. Physical and Chemical Charateristics of Milk. Variation due to Microwave Radiation. Croat. Chem. Acta 2011, 84, 429-433. [CrossRef]

11. Vaskova, H.; Buckova, M. Spectroscopic Measurement and Analysis of Fat in Mi. In Proceedings of the 26th International DAAAM Symposium 2016; Katalinic, B., Ed.; DAAAM International Vienna: Vienna, Austria, 2016; pp. 365-370, ISBN 9783902734075.

12. Bansal, B.K.; Hamann, J.; Grabowskit, N.T.; Singh, K.B. Variation in the composition of selected milk fraction samples from healthy and mastitic quarters, and its significance for mastitis diagnosis. J. Dairy Res. 2005, 72, 144-152. [CrossRef]

13. Mansbridge, R.J.; Blake, J.S. Nutritional factors affecting the fatty acid composition of bovine milk. Br. J. Nutr. 1997, 78 (Suppl. 1), S37-S47. [CrossRef]

14. Santiago, B.M.; da Silva, F.F.; Silva, R.R.; Costa, E.G.L.; Porto Junior, A.F.; Costa, E.N.; de Souza, D.D. Effect of different roughages sources on performance, milk composition, fatty acid profile, and milk cholesterol content of feedlot feed crossbred cows (Holstein $\times$ Zebu). Trop. Anim. Health Prod. 2019, 51, 599-604. [CrossRef]

15. Pereira, R.; Vicente, A. Novel Technologies for Milk Processing. In Engineering Aspects of Milk and Dairy Products; Coimbra, J., Teixeira, J., Eds.; CRC Press: Boca Raton, FL, USA, 2009; pp. 155-174, ISBN 978-1-4200-9022-2.

16. Jensen, R.G. Handbook of Milk Composition; Academic Press: San Diego, CA, USA, 1995; ISBN 9780080533117.

17. Pereira, P.C. Milk nutritional composition and its role in human health. Nutrition 2014, 30, 619-627. [CrossRef]

18. Poonia, A.; Jha, A.; Sharma, R.; Singh, H.B.; Rai, A.K.; Sharma, N. Detection of adulteration in milk: A review. Int. J. Dairy Technol. 2017, 70, 23-42. [CrossRef]

19. Bauman, D.E.; Griinari, J.M. Nutritional regulation of milk fat synthesis. Annu. Rev. Nutr. 2003, 23, $203-227$. [CrossRef] [PubMed]

20. Palmquist, D.L. Milk Fat: Origin of Fatty Acids and Influence of Nutritional Factors Thereon. In Advanced Dairy Chemistry Volume 2 Lipids; Fox, P.F., McSweeney, P.L.H., Eds.; Springer: Boston, MA, USA, 2006; pp. 43-92, ISBN 978-0-387-26364-9.

21. Keenan, T.W.; Mather, I.H. Intracellular origin of milk fat globules and the nature of the milk fat globule membrane. In Advanced Dairy Chemistry Volume 2 Lipids; Fox, P.F., McSweeney, P.L.H., Eds.; Springer: Boston, MA, USA, 2006; pp. 137-171, ISBN 978-0-387-26364-9.

22. Azad, T.; Ahmed, S. Common milk adulteration and their detection techniques. Food Contam. $2016,3$. [CrossRef]

23. Kala, R.; Samková, E.; Hanuš, O.; Pecová, L.; Sekmokas, K.; Riaukienè, D. Milk Protein Analysis: An Overview of the Methods-Development and Application. Acta Univ. Agric. Silv. Mendel. Brun. 2019, 67, 345-359. [CrossRef]

24. Bhat, M.Y.; Dar, T.A.; Singh, L.R. Casein Proteins: Structural and Functional Aspects. In Milk Proteins-From Structure to Biological Properties and Health Aspects; Gigli, I., Ed.; InTech: London, UK, 2016; ISBN 978-953-51-2536-5.

25. Walstra, P.; Walstra, P.; Wouters, J.T.M.; Geurts, T.J. Dairy Science and Technology; CRC Press: Boca Raton, FL, USA, 2005; ISBN 9780429116148.

26. Rizzoli, R. Dairy products, yogurts, and bone health. Am. J. Clin. Nutr. 2014, 99, 1256S-1262S. [CrossRef] 
27. Evershed, R.; Temple, N. Sorting the Beef from the Bull. The Science of Food Fraud Forensics/Richard Evershed E Nicola Temple; Bloomsbury Sigma: London, UK, 2016; ISBN 9781472911339.

28. Dave, A.; Banwari, D.; Srivastava, S.; Sadistap, S. Optical sensing system for detecting water adulteration in milk. In Proceedings of the Global Humanitarian Technology Conference (GHTC), Seattle, WA, USA, 13-16 October 2016; pp. 634-639, ISBN 978-1-5090-2432-2.

29. Fox, P.F.; Uniacke-Lowe, T.; McSweeney, P.L.H.; O'Mahony, J.A. Water in Milk and Dairy Products. In Dairy Chemistry and Biochemistry; Fox, P.F., Uniacke-Lowe, T., McSweeney, P.L.H., O'Mahony, J.A., Eds.; Springer International Publishing: Cham, Switzerland, 2015; pp. 299-320, ISBN 978-3-319-14891-5.

30. Inácio, M.R.C.; de Moura, M.F.V.; de Lima, K.M.G. Classification and determination of total protein in milk powder using near infrared reflectance spectrometry and the successive projections algorithm for variable selection. Vib. Spectrosc. 2011, 57, 342-345. [CrossRef]

31. Olson, B.J.S.C.; Markwell, J. Assays for determination of protein concentration. Curr. Protoc. Protein Sci. 2007, 38, A.3A.1-A.3A.29. [CrossRef]

32. ISO. IDF 105:2008 Milk-Determination of Fat Content-Gerber Butyrometers. Available online: https: //www.iso.org/standard/51018.html (accessed on 2 September 2020).

33. Xin, Q.; Ling, H.Z.; Long, T.J.; Zhu, Y. The rapid determination of fat and protein content in fresh raw milk using the laser light scattering technology. Opt. Lasers Eng. 2006, 44, 858-869. [CrossRef]

34. Agranovich, D.; Ben Ishai, P.; Katz, G.; Bezman, D.; Feldman, Y. Dielectric spectroscopy study of water dynamics in frozen bovine milk. Colloids Surf. B Biointerfaces 2016, 141, 390-396. [CrossRef] [PubMed]

35. Huang, H.; Yu, H.; Xu, H.; Ying, Y. Near infrared spectroscopy for on/in-line monitoring of quality in foods and beverages: A review. J. Food Eng. 2008, 87, 303-313. [CrossRef]

36. ISO (International Organization for Standardization). Whole Milk—Determination of Milk Fat, Protein and Lactose Content-Guidance on the Operation of Mid-Infrared Instruments; International Standard ISO 9622:2000/IDF 141C:2000; International Dairy Federation: Brussels, Belgium, 2000.

37. Priev, D.; Ponomarev, V.; Priev, A. Acoustic radiation forces in monitoring of milk composition. J. Acoust. Soc. Am. 2008, 123, 3789. [CrossRef]

38. Manske, G.A.; Rigo, E.; Gomes, F.J.; Schogor, A.L.B. Infrared or ultrasonic milk analysis can affect its results? Cienc. Rural 2019, 49. [CrossRef]

39. Operation Manual for Klever-2. Available online: https://www.kleverltd.ru (accessed on 8 August 2020).

40. Manual for the Operation of Lactan. Available online: https://sibagropribor.ru/ (accessed on 8 August 2020).

41. Ekomilk Operation Manual. Available online: http://ekomilk.ru/ (accessed on 8 August 2020).

42. Lactoscan Operation Manual. Available online: https://www.milkotronic.com/downloads.html (accessed on 8 August 2020).

43. Operation Manual for Bentley. Available online: http://www.bentleyplemtech.ru/ (accessed on 8 August 2020).

44. Zhu, Z.; Guo, W. Recent developments on rapid detection of main constituents in milk: A review. Crit. Rev. Food Sci. Nutr. 2020, 1-13. [CrossRef] [PubMed]

45. Mäntele, W.; Deniz, E. UV-VIS absorption spectroscopy: Lambert-Beer reloaded. Spectrochim. Acta Part A Mol. Biomol. Spectrosc. 2017, 173, 965-968. [CrossRef]

46. Gupta, K.; Shenoy, M.R. Method to determine the anisotropy parameter g of a turbid medium. Appl. Opt. 2018, 57, 7559-7563. [CrossRef]

47. Aernouts, B.; Van Beers, R.; Watté, R.; Huybrechts, T.; Lammertyn, J.; Saeys, W. Visible and near-infrared bulk optical properties of raw milk. J. Dairy Sci. 2015, 98, 6727-6738. [CrossRef]

48. Steponavičius, R.; Thennadil, S.N. Full correction of scattering effects by using the radiative transfer theory for improved quantitative analysis of absorbing species in suspensions. Appl. Spectrosc. 2013, 67, 526-535. [CrossRef]

49. Regnima, G.O.; Koffi, T.; Bagui, O.; Kouacou, A.; Kristensson, E.; Zoueu, J.; Berrocal, E. Quantitative measurements of turbid liquids via structured laser illumination planar imaging where absorption spectrophotometry fails. Appl. Opt. 2017, 56, 3929-3938. [CrossRef]

50. Stocker, S.; Foschum, F.; Krauter, P.; Bergmann, F.; Hohmann, A.; Happ, C.S.; Kienle, A. Broadband Optical Properties of Milk. Appl. Spectrosc. 2017, 71, 951-962. [CrossRef]

51. Michalski, M.-C.; Briard, V.; Michel, F. Optical parameters of milk fat globules for laser light scattering measurements. Lait 2001, 81, 787-796. [CrossRef] 
52. Aernouts, B.; van Beers, R.; Watté, R.; Huybrechts, T.; Jordens, J.; Vermeulen, D.; Gerven, T.V.; Lammertyn, J.; Saeys, W. Effect of ultrasonic homogenization on the Vis/NIR bulk optical properties of milk. Colloids Surf. $B$ Biointerfaces 2015, 126, 510-519. [CrossRef]

53. Tsenkova, R.; Atanassova, S.; Kawano, S.; Toyoda, K. Somatic cell count determination in cow's milk by near-infrared spectroscopy: A new diagnostic tool. J. Anim. Sci. 2001, 79, 2550-2557. [CrossRef] [PubMed]

54. Stefanescu, R.; Brebu, S.; Matei, M.; Risca, I.M.; Surleva, A.; Drochioiu, G. Contribution to casein determination by UV spectrophotometry. Acta Chem. Iasi. 2017, 25, 112-126. [CrossRef]

55. McCarthy, O.J. Physical and Physico-Chemical Properties of Milk. In Encyclopedia of Dairy Sciences; Elsevier: Amsterdam, The Netherlands, 2002; Volume 3, pp. 467-477, ISBN 9780123744029.

56. Xiong, S.; Adhikari, B.; Chen, X.D.; Che, L. Determination of ultra-low milk fat content using dual-wavelength ultraviolet spectroscopy. J. Dairy Sci. 2016, 99, 9652-9658. [CrossRef]

57. Miller, E.S.; Mackinney, G.; Zscheile, F.P. Absorption spectra of alpha and beta carotenes and lycopene. Plant Physiol. 1935, 10, 375-381. [CrossRef]

58. Koziol, J. Studies on flavins in organic solvents-i. Spectral characteristics of riboflavin, riboflavin tetrabutyrate and lumichrome. Photochem. Photobiol. 1966, 5, 41-54. [CrossRef]

59. Wójcicki, K. Applying NIR spectroscopy to evaluate quality of whey protein supplements available on the polish market. Żywność Naukatechnologia Jakość 2018, 25, 59-70. [CrossRef]

60. Brandão, M.C.M.P.; Carmo, A.P.; Bell, M.J.V.; Anjos, V.C. Characterization of milk by infrared spectroscopy. Rev. Inst. Latic. Cândid. 2010, 65, 30-33.

61. Holroyd, S.E. The Use of near Infrared Spectroscopy on Milk and Milk Products. J. Near Infrared Spectrosc. 2013, 21, 311-322. [CrossRef]

62. Etzion, Y.; Linker, R.; Cogan, U.; Shmulevich, I. Determination of Protein Concentration in Raw Milk by Mid-Infrared Fourier Transform Infrared/Attenuated Total Reflectance Spectroscopy. J. Dairy Sci. 2004, 87, 2779-2788. [CrossRef]

63. Mohamed, H.; Nagy, P.; Agbaba, J.; Kamal-Eldin, A. Use of near and mid infra-red spectroscopy for analysis of protein, fat, lactose and total solids in raw cow and camel milk. Food Chem. 2020, 334, 127436. [CrossRef] [PubMed]

64. Bogomolov, A.; Belikova, V.; Galyanin, V.; Melenteva, A.; Meyer, H. Reference-free spectroscopic determination of fat and protein in milk in the visible and near infrared region below $1000 \mathrm{~nm}$ using spatially resolved diffuse reflectance fiber probe. Talanta 2017, 167, 563-572. [CrossRef] [PubMed]

65. Bogomolov, A.; Melenteva, A. Scatter-based quantitative spectroscopic analysis of milk fat and total protein in the region $400-1100 \mathrm{~nm}$ in the presence of fat globule size variability. Chemom. Intell. Lab. Syst. 2013, 126, 129-139. [CrossRef]

66. Bogomolov, A.; Dietrich, S.; Boldrini, B.; Kessler, R.W. Quantitative determination of fat and total protein in milk based on visible light scatter. Food Chem. 2012, 134, 412-418. [CrossRef]

67. Melenteva, A.; Galyanin, V.; Savenkova, E.; Bogomolov, A. Building global models for fat and total protein content in raw milk based on historical spectroscopic data in the visible and short-wave near infrared range. Food Chem. 2016, 203, 190-198. [CrossRef]

68. Goulden, J. Analysis of milk by infra-red absorption. J. Dairy Res. 1964, 3, 273-284. [CrossRef]

69. de Marchi, M.; Penasa, M.; Zidi, A.; Manuelian, C.L. Invited review: Use of infrared technologies for the assessment of dairy products-Applications and perspectives. J. Dairy Sci. 2018, 101, 10589-10604. [CrossRef]

70. Pereira, C.; Luiz, L.C.; Bell, M.J.V.; Anjos, V. Near and Mid Infrared Spectroscopy to Assess Milk Products Quality: A Review of Recent Applications. J. Dairy Res. Technol. 2020, 3, 100014. [CrossRef]

71. Balabin, R.M.; Safieva, R.Z.; Lomakina, E.I. Comparison of linear and nonlinear calibration models based on near infrared (NIR) spectroscopy data for gasoline properties prediction. Chemom. Intell. Lab. Syst. 2007, 88, 183-188. [CrossRef]

72. Balabin, R.M.; Safieva, R.Z.; Lomakina, E.I. Wavelet neural network (WNN) approach for calibration model building based on gasoline near infrared (NIR) spectra. Chemom. Intell. Lab. Syst. 2008, 93, 58-62. [CrossRef]

73. Andrade, J.; Guimarães Pereira, C.; de Almeida, J.C., Jr.; Viana, C.C.; de Oliveira Neves, L.N.; da Silva, P.H.; Bell, M.J.; dos Anjos, V.D. FTIR-ATR determination of protein content to evaluate whey protein concentrate adulteration. LWT 2019, 99, 166-172. [CrossRef] 
74. Balan, B.; Dhaulaniya, A.S.; Jamwal, R.; Sodhi, K.K.; Kelly, S.D.; Cannavan, A.; Singh, D.K. Application of Attenuated Total Reflectance-Fourier Transform Infrared (ATR-FTIR) spectroscopy coupled with chemometrics for detection and quantification of formalin in cow milk. Vib. Spectrosc. 2020, 107, 103033. [CrossRef]

75. Balan, B.; Dhaulaniya, A.S.; Jamwal, R.; Yadav, A.; Kelly, S.; Cannavan, A.; Singh, D.K. Rapid detection and quantification of sucrose adulteration in cow milk using Attenuated total reflectance-Fourier transform infrared spectroscopy coupled with multivariate analysis. Spectrochim. Acta A Mol. Biomol. Spectrosc. 2020, 240, 118628. [CrossRef]

76. Franzoi, M.; Niero, G.; Visentin, G.; Penasa, M.; Cassandro, M.; de Marchi, M. Variation of Detailed Protein Composition of Cow Milk Predicted from a Large Database of Mid-Infrared Spectra. Animals 2019, 9, 176. [CrossRef]

77. Cirak, O.; Icyer, N.; Durak, M. Rapid detection of adulteration of milks from different species using Fourier Transform Infrared Spectroscopy (FTIR). J. Dairy Res. 2018, 85, 222-225. [CrossRef] [PubMed]

78. Balabin, R.M.; Smirnov, S.V. Melamine detection by mid- and near-infrared (MIR/NIR) spectroscopy: A quick and sensitive method for dairy products analysis including liquid milk, infant formula, and milk powder. Talanta 2011, 85, 562-568. [CrossRef] [PubMed]

79. Botelho, B.G.; Reis, N.; Oliveira, L.S.; Sena, M.M. Development and analytical validation of a screening method for simultaneous detection of five adulterants in raw milk using mid-infrared spectroscopy and PLS-DA. Food Chem. 2015, 181, 31-37. [CrossRef]

80. Casarrubias-Torres, L.M.; Meza-Márquez, O.G.; Osorio-Revilla, G.; Gallardo-Velazquez, T. Mid-infrared spectroscopy and multivariate analysis for determination of tetracycline residues in cow's milk. Acta Vet. Brno 2018, 87, 181-188. [CrossRef]

81. Rienesl, L.; Khayatzadeh, N.; Köck, A.; Dale, L.; Werner, A.; Grelet, C.; Gengler, N.; Auer, F.J.; Egger-Danner, C.; Massart, X.; et al. Mastitis detection from milk mid-infrared (MIR) spectroscopy in dairy cows. Acta Univ. Agric. Silv. Mendel. Brun. 2019, 67, 1221-1226. [CrossRef]

82. Libnau, F.O.; Kvalheim, O.M.; Christy, A.A.; Toft, J. Spectra of water in the near- and mid-infrared region. Vib. Spectrosc. 1994, 7, 243-254. [CrossRef]

83. Linker, R.; Etzion, Y. Potential and limitation of mid-infrared attenuated total reflectance spectroscopy for real time analysis of raw milk in milking lines. J. Dairy Res. 2009, 76, 42-48. [CrossRef] [PubMed]

84. Aernouts, B.; Polshin, E.; Lammertyn, J.; Saeys, W. Visible and near-infrared spectroscopic analysis of raw milk for cow health monitoring: Reflectance or transmittance? J. Dairy Sci. 2011, 94, 5315-5329. [CrossRef] [PubMed]

85. Melfsen, A.; Holstermann, M.; Haeussermann, A.; Molkentin, J.; Susenbeth, A.; Hartung, E. Accuracy and application of milk fatty acid estimation with diffuse reflectance near-infrared spectroscopy. J. Dairy Res. 2018, 85, 212-221. [CrossRef]

86. Katsumata, T.; Aizawa, H.; Komuro, S.; Ito, S.; Matsumoto, T. Quantitative analysis of fat and protein concentrations of milk based on fibre-optic evaluation of back scattering intensity. Int. Dairy J. 2020, 109, 104743. [CrossRef]

87. Laporte, M.; Paquin, P. Near-infrared analysis of fat, protein, and casein in cow's milk. J. Agric. Food Chem. 1999, 47, 2600-2605. [CrossRef]

88. Tsenkova, R.; Atanassova, S.; Toyoda, K.; Ozaki, Y.; Itoh, K.; Fearn, T. Near-Infrared Spectroscopy for Dairy Management: Measurement of Unhomogenized Milk Composition. J. Dairy Sci. 1999, 82, 2344-2351. [CrossRef]

89. Melfsen, A.; Hartung, E.; Haeussermann, A. Accuracy of milk composition analysis with near infrared spectroscopy in diffuse reflection mode. Biosyst. Eng. 2012, 112, 210-217. [CrossRef]

90. Surkova, A.; Belikova, V.; Kirsanov, D.; Legin, A.; Bogomolov, A. Towards an optical multisensor system for dairy: Global calibration for fat analysis in homogenized milk. Microchem. J. 2019, 149, 104012. [CrossRef]

91. Mazivila, S.J.; Páscoa, R.N.M.J.; Castro, R.C.; Ribeiro, D.S.M.; Santos, J.L.M. Detection of melamine and sucrose as adulterants in milk powder using near-infrared spectroscopy with DD-SIMCA as one-class classifier and MCR-ALS as a means to provide pure profiles of milk and of both adulterants with forensic evidence: A short communication. Talanta 2020, 216, 120937. [CrossRef]

92. Kamboj, U.; Kaushal, N.; Jabeen, S. Near Infrared Spectroscopy as an efficient tool for the Qualitative and Quantitative Determination of Sugar Adulteration in Milk. J. Phys. Conf. Ser. 2020, 1531, 012024. [CrossRef] 
93. Mabood, F.; Ali, L.; Boque, R.; Abbas, G.; Jabeen, F.; Haq, Q.M.; Hussain, J.; Hamaed, A.M.; Naureen, Z.; Al-Nabhani, M.; et al. Robust Fourier transformed infrared spectroscopy coupled with multivariate methods for detection and quantification of urea adulteration in fresh milk samples. Food Sci. Nutr. 2019, 1-10. [CrossRef]

94. Tsenkova, R.; Meilina, H.; Kuroki, S.; Burns, D.H. Near infrared spectroscopy using short wavelengths and leave-one-cow-out cross-validation for quantification of somatic cells in milk. J. Near Infrared Spectrosc. 2009, 17, 345-351. [CrossRef]

95. Yang, B.; Zhu, Z.; Gao, M.; Yan, X.; Zhu, X.; Guo, W. A portable detector on main compositions of raw and homogenized milk. Comput. Electron. Agric. 2020, 177, 105668. [CrossRef]

96. Kawasaki, M.; Kawamura, S.; Tsukahara, M.; Morita, S.; Komiya, M.; Natsuga, M. Near-infrared spectroscopic sensing system for on-line milk quality assessment in a milking robot. Comput. Electron. Agric. 2008, 63, 22-27. [CrossRef]

97. Diaz-Olivares, J.A.; Adriaens, I.; Stevens, E.; Saeys, W.; Aernouts, B. Online Milk Composition Analysis with an On-farm Near-Infrared Sensor. Available Online: https://www.biorxiv.org/content/10.1101/2020.06.02. 129742v1.full.pdf (accessed on 15 October 2020).

98. Aleixo, P.C.; Nóbrega, J.A. Direct determination of iron and selenium in bovine milk by graphite furnace atomic absorption spectrometry. Food Chem. 2003, 83, 457-462. [CrossRef]

99. Birghila, S.; Dobrinas, S.; Stanciu, G.; Soceanu, A. Determination of major and minor elements in milk through ICP-AES. Environ. Eng. Manag. J. 2008, 7, 805-808. [CrossRef]

100. Asfaw, A.; Wibetoe, G. Simultaneous determination of hydride (Se) and non-hydride-forming (Ca, Mg, K, P, $\mathrm{S}$ and $\mathrm{Zn}$ ) elements in various beverages (beer, coffee, and milk), with minimum sample preparation, by ICP-AES and use of a dual-mode sample-introduction system. Anal. Bioanal. Chem. 2005, 382, 173-179. [CrossRef]

101. Mazurek, S.; Szostak, R.; Czaja, T.; Zachwieja, A. Analysis of milk by FT-Raman spectroscopy. Talanta 2015, 138, 285-289. [CrossRef]

102. He, H.; Sun, D.-W.; Pu, H.; Chen, L.; Lin, L. Applications of Raman spectroscopic techniques for quality and safety evaluation of milk: A review of recent developments. Crit. Rev. Food Sci. Nutr. 2019, 595, 770-793. [CrossRef]

103. Reiner, J.; Protte, K.; Hinrichs, J. Investigation of the Applicability of Raman Spectroscopy as Online Process Control during Consumer Milk Production. Chem. Eng. 2020, 4, 45. [CrossRef]

104. Soulat, J.; Andueza, D.; Graulet, B.; Girard, C.L.; Labonne, C.; Aït-Kaddour, A.; Martin, B.; Ferlay, A. Comparison of the potential abilities of three spectroscopy methods: Near-infrared, mid-infrared, and molecular fluorescence, to predict carotenoid, vitamin and fatty acid contents in cow milk. Foods 2020, 9, 592. [CrossRef]

105. Ntakatsane, M.; Chen, P.; Liu, J.; Mosebi, P.; Xu, L.; Matebesi, P.; Wang, Y. Multi-dimensional fluorescence spectroscopy coupled with chemometrics in rapid antibiotic detection and discrimination. J. Food Meas. Charact. 2020, 14, 1892-1900. [CrossRef]

106. Genis, D.O.; Bilge, G.; Sezer, B.; Durna, S.; Boyaci, I.H. Identification of cow, buffalo, goat and ewe milk species in fermented dairy products using synchronous fluorescence spectroscopy. Food Chem. 2019, 284, 60-66. [CrossRef] [PubMed]

107. Yang, Y.; Hettinga, K.A.; Erasmus, S.W.; Pustjens, A.M.; van Ruth, S.M. Opportunities for fraudsters: When would profitable milk adulterations go unnoticed by common, standardized FTIR measurements? Food Res. Int. 2020, 136, 109543. [CrossRef]

108. Villa-Arango, S.; Torres, R.; Kyriacou, P.A.; Lucklum, R. Acoustic spectrometer: Resonant sensing platform for measuring volumetric properties of liquid samples. In Proceedings of the VII Latin American Congress on Biomedical Engineering CLAIB 2016, Bucaramanga, Santander, Colombia, 26-28 October 2016; Torres, I., Bustamante, J., Sierra, D.A., Eds.; Springer: Singapore, 2017; pp. 70-73, ISBN 978-981-10-4085-6.

109. Szabo, T.L. Diagnostic Ultrasound Imaging. Inside out/Thomas L. Szabo; Elsevier Academic Press: Amsterdam, The Netherlands; Oxford, UK, 2004; ISBN 0-12-680145-2.

110. Mohammadi, V.; Ghasemi-Varnamkhasti, M.; Ebrahimi, R.; Abbasvali, M. Ultrasonic techniques for the milk production industry. Measurement 2014, 58, 93-102. [CrossRef]

111. Ali, M.-H.; Ahmad, A. Attenuation of ultrasound in reconstituted milk. Int. J. Sci. Environ. Technol. 2017, 6, $1828-1832$. 
112. Adami, A.; Mortari, A.; Morganti, E.; Lorenzelli, L. Microfluidic Sample Preparation Methods for the Analysis of Milk Contaminants. J. Sens. 2016, 2016, 1-9. [CrossRef]

113. Dukhin, A.S.; Goetz, P.J.; Travers, B. Use of ultrasound for characterizing dairy products. J. Dairy Sci. 2005, 88, 1320-1334. [CrossRef]

114. Elvira, L.; Rodríguez, J.; Lynnworth, L.C. Sound speed and density characterization of milk adulterated with melamine. J. Acoust. Soc. Am. 2009, 125, EL177-EL182. [CrossRef]

115. Halachmi, I.; Guarino, M.; Bewley, J.; Pastell, M. Smart Animal Agriculture: Application of Real-Time Sensors to Improve Animal Well-Being and Production. Annu. Rev. Anim. Biosci. 2019, 7, 403-425. [CrossRef] [PubMed]

116. Mohammadi, V.; Ghasemi-Varnamkhasti, M.; González, L.A. Analytical measurements of ultrasound propagation in dairy products: A review. Trends Food Sci. Technol. 2017, 61, 38-48. [CrossRef]

117. McClements, D.J. Ultrasonic characterization of foods and drinks: Principles, methods, and applications. Crit. Rev. Food Sci. Nutr. 1997, 37, 1-46. [CrossRef]

118. De Luca, M.; Santonico, M.; Pennazza, G.; Iarossi, S. Ultrasound based sensor for fat detection in fresh milk. In Sensors; Baldini, F., D’Amico, A., Di Natale, C., Siciliano, P., Seeber, R., de Stefano, L., Bizzarri, R., Andò, B., Eds.; Springer: New York, NY, USA, 2014; pp. 499-502, ISBN 978-1-4614-3859-5.

119. Munir, M.; Nadeem, M.; Qureshi, T.M.; Leong, T.S.H.; Gamlath, C.J.; Martin, G.J.O.; Ashokkumar, M. Effects of high pressure, microwave and ultrasound processing on proteins and enzyme activity in dairy systems-A review. Innov. Food Sci. Emerg. Technol. 2019, 57, 102192. [CrossRef]

120. Paniwnyk, L. Applications of ultrasound in processing of liquid foods: A review. Ultrason. Sonochem. 2017, 38, 794-806. [CrossRef] [PubMed]

121. Murray, B.S.; Deshaires, C. Monitoring protein fouling of metal surfaces via a quartz crystal microbalance. J. Colloid Interface Sci. 2000, 227, 32-41. [CrossRef] [PubMed]

122. Gan, T.H.; Pallav, P.; Hutchins, D.A. Non-contact ultrasonic quality measurements of food products. J. Food Eng. 2006, 77, 239-247. [CrossRef]

123. Dukhin, A.S.; Goetz, P.J. Ultrasound for Characterizing Colloids. Particle Sizing, Zeta Potential, Rheology; Elsevier: Amsterdam, The Netherlands, 2002.

124. McClements, D.J. Ultrasonic characterisation of emulsions and suspensions. Adv. Colloid Interface Sci. 1991, 37, 33-72. [CrossRef]

125. Natta, G.; Baccaredda, M. Sulla velocita di propagazione degli ultrasuoni nelle miscele ideali. Atti Accad. Naz. Lincei-Rend. Sc. Fis. Mat. Nat. 1948, 4, 360-366.

126. Rowlinson, J.S.; Swinton, F. Liquids and Liquid Mixtures, 3rd ed.; Butterworth Scientific: Oxford, UK, 1982.

127. Flory, P.J. Statistical Thermodynamics of Liquid Mixtures. J. Am. Chem. Soc. 1965, 87, 1833-1838. [CrossRef]

128. Hahn, P.; Dual, J. A numerically efficient damping model for acoustic resonances in microfluidic cavities. Phys. Fluids 2015, 27, 62005. [CrossRef]

129. Trujillo, F.J.; Juliano, P.; Barbosa-Cánovas, G.; Knoerzer, K. Separation of suspensions and emulsions via ultrasonic standing waves-A review. Ultrason. Sonochem. 2014, 21, 2151-2164. [CrossRef] [PubMed]

130. Fox, P.F.; Uniacke-Lowe, T.; McSweeney, P.L.H.; O’Mahony, J.A. Physical Properties of Milk. In Dairy Chemistry and Biochemistry; Fox, P.F., Uniacke-Lowe, T., McSweeney, P.L.H., O'Mahony, J.A., Eds.; Springer International Publishing: Cham, Switzerland, 2015; pp. 321-343, ISBN 978-3-319-14891-5.

131. McCarthy, O.J.; Singh, H. Physico-chemical Properties of Milk. In Advanced Dairy Chemistry; McSweeney, P., Fox, P.F., Eds.; Springer: New York, NY, USA, 2009; pp. 691-758, ISBN 978-0-387-84864-8.

132. Singh, H.; McCarthy, O.J.; Lucey, J.A. Physico-Chemical Properties of Milk. In Advanced Dairy Chemistry Volume 3; Fox, P.F., Ed.; Springer: Boston, MA, USA, 1997; pp. 469-518, ISBN 978-1-4757-4411-8.

133. Russel, W.B. Brownian motion of small particles suspended in liquids. Annu. Rev. Fluid Mech. 1981, 13, 425-455. [CrossRef]

134. Caprita, R.; Caprita, A.; Benscik, I.; Cretescu, I. The Influence of Milk Protein Content on the Surface Tension and Viscosity. Acta Vet. Scand. 2003, 44, P86. [CrossRef]

135. Vives, A.A. Piezoelectric Transducers and Applications; Springer: Berlin/Heidelberg, Germany, 2008; ISBN 978-3-540-77507-2.

136. Elvira, L.; Sampedro, L.; de Espinosa, F.M.; Matesanz, J.; Gómez-Ullate, Y.; Resa, P.; Echevarría, F.J.; Iglesias, J.R. Eight-channel ultrasonic device for non-invasive quality evaluation in packed milk. Ultrasonics 2006, 45, 92-99. [CrossRef] 
137. McClements, D.J. Advances in the application of ultrasound in food analysis and processing. Trends Food Sci. Technol. 1995, 6, 293-299. [CrossRef]

138. Saxena, I.; Pathak, R.N.; Kumar, V.; Devi, R. Introduction of ultrasonic interferometer and experimental techniques for determination of ultrasonic velocity, density, viscosity and various thermodynamic parameters. Int. J. Appl. Res. 2015, 1, 562-569. [CrossRef]

139. Kucera, D.M.; Ketterson, J.B. Variable path cryogenic acoustic interferometer. Rev. Sci. Instrum. 1998, 69, 4156-4159. [CrossRef]

140. Sharma, S.; Mishra, U.K.; Yadav, S.; Dubey, P.K. Improved ultrasonic interferometer technique for propagation velocity and attenuation measurement in liquids. Rev. Sci. Instrum. 2019, 90, 45107. [CrossRef] [PubMed]

141. Inoue, N.; Hirai, M.; Hasegawa, T.; Matsuzawa, K. A new ultrasonic interferometer for velocity measurement in liquids using optical diffraction. J. Phys. D Appl. Phys. 1986, 19, 1439-1447. [CrossRef]

142. Gülseren, I.; Alexander, M.; Corredig, M. Probing the colloidal properties of skim milk using acoustic and electroacoustic spectroscopy. Effect of concentration, heating and acidification. J. Colloid Interface Sci. 2010, 351, 493-500. [CrossRef] [PubMed]

143. Martin, S.J.; Wessendorf, K.O.; Gebert, C.T.; Frye, G.C.; Cernosek, R.W.; Casaus, L.; Mitchell, M.A. Measuring liquid properties with smooth- and textured-surface resonators. In Proceedings of the Annual Frequency Control Symposium, Salt Lake City, UT, USA, 2 June 1993; pp. 603-608. [CrossRef]

144. Ito, T.; Aoki, N.; Tsuchiya, A.; Kaneko, S.; Akiyama, K.; Uetake, K.; Suzuki, K. Detection of Stress Hormone in the Milk for Animal Welfare Using QCM Method. J. Sens. 2017, 2017, 1-7. [CrossRef]

145. Sakti, S.P.; Chabibah, N.; Ayu, S.P.; Padaga, M.C.; Aulanni'am, A.A. Development of QCM Biosensor with specific cow milk protein antibody for candidate milk adulteration detection. J. Sens. 2016, 2016, 1-7. [CrossRef]

146. Mukhin, N.; Kutia, M.; Oseev, A.; Palis, S.; Steinmann, U.; Lucklum, R. Narrow band solid-liquid composite arrangements: Alternative solutions for phononic crystal-based liquid sensors. Sensors 2019, 19, 3743. [CrossRef] [PubMed]

147. Mukhin, N.; Lucklum, R. QCM based sensor for detecting volumetric properties of liquids. Curr. Appl. Phys. 2019, 19, 679-682. [CrossRef]

148. Oseev, A.; Lucklum, R.; Zubtsov, M.; Schmidt, M.-P.; Mukhin, N.V.; Hirsch, S. SAW-Based Phononic Crystal Microfluidic Sensor-Microscale Realization of Velocimetry Approaches for Integrated Analytical Platform Applications. Sensors 2017, 17, 2187. [CrossRef] [PubMed]

149. Lucklum, R.; Zubtsov, M.; Oseev, A. Phoxonic crystals-A new platform for chemical and biochemical sensors. Anal. Bioanal. Chem. 2013, 405, 6497-6509. [CrossRef]

Publisher's Note: MDPI stays neutral with regard to jurisdictional claims in published maps and institutional affiliations.

(C) 2020 by the authors. Licensee MDPI, Basel, Switzerland. This article is an open access article distributed under the terms and conditions of the Creative Commons Attribution (CC BY) license (http://creativecommons.org/licenses/by/4.0/). 